\title{
Taxonomic relationships of the [Pasteurella] haemolytica complex as evaluated by DNA-DNA hybridizations and 165 rRNA sequencing with proposal of Mannheimia haemolytica gen. nov., comb. nov., Mannheimia granulomatis comb. nov., Mannheimia glucosida sp. nov., Mannheimia ruminalis sp. nov. and Mannheimia varigena sp. nov.
}

\author{
Øystein Angen, ${ }^{1} \dagger$ Reinier Mutters, ${ }^{2}$ Dominique A. Caugant, ${ }^{3}$ \\ John E. Olsen ${ }^{1}$ and Magne Bisgaard ${ }^{1}$
}

Author for correspondence: Øystein Angen. Fax: +45 35300120. e-mail: ang@svs.dk

1 Department of Veterinary Microbiology, The Royal Veterinary and

Agricultural University, Bülowsvej 13, DK-1870 Frederiksberg C, Denmark

2 Institut für Medizinische Mikrobiologie, Klinikum der Philipps-Universtät, Pilgrimstein 2, D-35037 Marburg, Germany

3 National Institute of Public Health, Department of Bacteriology, PO Box 4404 Torshov, 0403 Oslo, Norway

\begin{abstract}
The present paper presents the conclusions of a polyphasic investigation of the taxonomy of the trehalose-negative [Pasteurella] haemolytica complex. Clusters previously identified by ribotyping and multilocus enzyme electrophoresis (MEE) have been evaluated by 165 rRNA sequencing and DNA-DNA hybridizations. Results obtained by the different techniques were highly related and indicated that the $[P$.] haemolytica complex contains distinct genetic and phenotypic groups. At least seven species were outlined, five of which were named. We refrained in formal naming of more groups until additional strains are characterized. Five 165 rRNA clusters were identified corresponding to distinct lineages previously outlined by MEE. Within 165 rRNA cluster I two distinct genotypic groups have been outlined in addition to [P.] haemolytica sensu stricto (biogroup 1). Each of the clusters II, III, IV and V represent at least one new species. The investigations underline that $[P$.] haemolytica sensu stricto only contains strains that do not ferment L-arabinose even though they are referred to as 'biotype $A$ ' of $[P$.] haemolytica. The five 165 rRNA clusters identified had a common root relative to the other species within the family Pasteurellaceae, and the overall sequence similarity among these five clusters was higher than what is observed within the existing genera of the family. The allocation of the trehalose-negative [P.] haemolytica complex to a new genus seems to be indicated. Based on the polyphasic investigation performed a new genus Mannheimia is proposed for the trehalose-negative [P.] haemolytica complex. At the present stage two previously named species are transferred to this new genus and three new species are described. [P.] haemolytica is reclassified as Mannheimia haemolytica comb. nov., whereas Pasteurella granulomatis, Bisgaard taxon 20 and $[P$.] haemolytica biovar $3 \mathrm{~J}$ are reclassified and combined in the species Mannheimia granulomatis comb. nov. Mannheimia glucosida sp. nov.
\end{abstract}




\begin{abstract}
corresponds to $[P$.] haemolytica biogroups $3 A-3 H$ and the $\beta$-glucosidase and meso-inositol-positive strains of [P.] haemolytica biogroup 9. All typable strains within $M$. glucosida belong to serotype 11. Mannheimia ruminalis sp. nov. consists of strains previously classified as Bisgaard taxon 18 and $[P$.] haemolytica biogroup 8D. Finally, Mannheimia varigena sp. nov. includes $[P$.] haemolytica biogroup 6 as well as Bisgaard taxon 15 and Bisgaard taxon 36. The type strains are NCTC $9380^{\top}$ (M. haemolytica), ATCC 49244' (M. granulomatis), CCUG 38457 ${ }^{\top}=$ P925 $^{\top}$ (M. glucosida), CCUG $38470^{\top}=$ HPA92 $^{\top}$ (M. ruminalis) and CCUG $38462^{\top}=177^{\top}$ (M. varigena).
\end{abstract}

Keywords: Pasteurella haemolytica, Mannheimia gen. nov., DNA-DNA hybridization, 16S rRNA sequencing, polyphasic taxonomy

\section{INTRODUCTION}

In 1921, Jones reported on three groups of bovine pasteurellae and placed atypical strains in group I of 'Bacillus bovisepticus' (Jones, 1921). These strains were further characterized by Newsom \& Cross (1932), who proposed the name [Pasteurella] haemolytica for group I of Bacillus bovisepticus. Two biotypes of $[P$.] haemolytica were described by Smith $(1959,1961)$ based upon a number of phenotypic characters as well as epidemiological and pathological differences. The biotypes were designated $\mathrm{A}$ and $\mathrm{T}$ referring to their ability to ferment either L-arabinose or trehalose. A third taxon of $[P$.] haemolytica was proposed by Frederiksen (1973) for strains which did not fit into the A/T biotyping pattern.

A serotyping system using an indirect haemagglutination test (IHA) was developed by Biberstein $e t$ al. (1960). Biberstein \& Gills (1962) subsequently reported a consistent association between serotypes and biotypes. The number of recognized serotypes has subsequently increased to 17 (Pegram et al., 1979; Fraser et al., 1982; Fodor et al., 1987; Younan \& Wallmann, 1989). Serotypes 3, 4, 10 and 15 are associated with biotype $T$, and the remaining serotypes with biotype A. Untypable strains by IHA have subsequently been characterized by counter-current immunoelectrophoresis (Donachie et al., 1984), demonstrating nine additional serogroups.

A number of investigators have reported difficulties in obtaining L-arabinose fermentation with some trehalose-negative strains even though these strains by other criteria represent strains of biotype A (Mraz, 1969; Bisgaard, 1984). Additionally, conflicting results have been obtained in different laboratories (Mraz, 1969). Extended phenotypic investigations in the mid1980 s showed that strains from ruminants classified as $[P$.] haemolytica could be divided into 12 biogroups based upon ornithine decarboxylase and fermentation of L-arabinose, D-sorbitol, glucosides (aesculin, amygdalin, arbutin, cellobiose, gentibiose and salicin) and trehalose (Mutters et al., 1989). DNA-DNA hybridizations (Mutters et al., 1986) have shown that some of the biogroups represent separate species and that $[P$.] haemolytica sensu stricto $([P$.] haemolytica biogroup 1) should only consist of strains negative for fermentation of L-arabinose. However, biotyping has only been used in a few laboratories, so at present there is little knowledge about the prevalence of the different biogroups and their veterinary importance. This situation is undesirable as it makes interpretation of studies on strains classified as $[P$.] haemolytica difficult, and it may hinder progress in studies on epidemiology and pathogenesis.

$[P$.] haemolytica was excluded from the genus Pasteurella sensu stricto in 1985 on the basis of DNA-DNA hybridizations (Mutters et al., 1985), and its separation from the three recognized genera within the family Pasteurellaceae was later supported by DNA-rRNA hybridizations (De Ley et al., 1990) and 16S rRNA sequencing (Dewhirst et al., 1992, 1993). Genotypic investigations have also shown that the trehalose-positive strains represent a separate species (Biberstein \& Francis, 1968; Pohl, 1979; Mannheim, 1983). Although these strains show no close affiliation to the genus Pasteurella, they were recently named Pasteurella trehaiosi (Sneath \& Stevens, 1990).

Studies on the 16S rRNA sequence variation among the different serotypes of $[P$.] haemolytica have recently been published showing that most of the typable 'biotype $A^{\prime}$ isolates had identical 16S rRNA sequences. Serotypes 2 and 11, however, showed deviations in two and four sequence positions, respectively (Davies et al., 1996). Untypable groups (UGs) identified by outer-membrane proteins and LPS variation were also described. UG4 and UG5 only showed $95 \cdot 3-96.0 \%$ sequence similarity with the type strain, indicating that they might represent new species. However, no attempt was made to classify these groups with the previously described biogroups.

The phenotypic and genotypic diversity of the trehalose-negative $[P$.] haemolytica complex has recently been investigated using quantitative evaluation of phenotypic data, ribotyping and multilocus enzyme electrophoresis (MEE) (Angen et al., 1997a, b, c). These studies also included taxa related to the $[P$.] haemolytica complex including: Pasteurella granulo- 
matis, Bisgaard taxon 18 and Bisgaard taxon 36, all of which have been isolated from ruminants, Bisgaard taxon 15 isolated from pigs and Bisgaard taxon 20 isolated from hares and rabbits. It was shown that the clusters found by numerical analysis of quantitative phenotypic data generally corresponded to genotypic clusters identified by ribotyping and MEE, and that sub-groups within the previously described biogroups also could be outlined.

The taxonomic consequences of these observations are only indicative. However, DNA-DNA hybridizations performed between a few selected strains representing biogroups 1, 3A, 3G, 3H, 9, taxon 15 and [ $P$.] trehalosi (Mutters et al., 1986) in addition to selected serotypes of $[P$.$] haemolytica and [P$.] trehalosi (Bingham et al., 1990 ) indicate that the trehalose-negative group might represent a new genus within the family Pasteurellaceae Pohl 1981 (Mutters et al., 1986). 16S rRNA sequences subsequently available for selected strains representing biogroup 1 , taxon 15 , taxon 18 , taxon 20 and $[P$.] trehalosi also show that with the exception of $[P$.] trehalosi these organisms are phylogenetically related (Davies et al., 1996). In the present investigation, strains representing the genotypic clusters previously outlined have been examined by $16 \mathrm{~S}$ rRNA sequencing and DNA-DNA hybridizations to achieve information about the phylogenetic structure and taxonomic distances within the $[P$.] haemolytica complex.

\section{METHODS}

Bacterial strains and phenotypic characterization. The selection of strains was based upon previous investigations including quantitative evaluation of phenotypic test results from 339 isolates representing different taxa within the trehalose-negative [P.] haemolytica complex (Angen et al., $1997 \mathrm{a}, \mathrm{b}$ ), ribotyping of 201 isolates (Angen et al., 1997c) and characterization of 59 isolates by MEE (Angen et al., 1997c). The polyphasic approach was used to ensure that strains chosen for $16 \mathrm{~S}$ rRNA sequencing and DNA--DNA hybridization covered the genotypic diversity known so far. Strains selected for $16 \mathrm{~S}$ rRNA sequencing and sequences from GenBank used for comparison are listed in Table 1. The bacterial strains used in the DNA homology studies are listed in Table 2. Materials and methods used to determine the phenotypic and genotypic (ribotyping and MEE) characteristics of the strains have been described previously (Angen et al., 1997a, c).

165 rRNA sequencing. One millilitre of an overnight culture grown with shaking in Tryptic Soy Broth (Difco) was centrifuged at 12000 r.p.m. for $2 \mathrm{~min}$, washed in $0.9 \%$

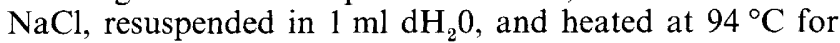
$20 \mathrm{~min}$. After centrifugation at 12000 r.p.m. for $2 \mathrm{~min}, 5 \mu \mathrm{l}$ lysate was added to $95 \mu \mathrm{l} \mathrm{PCR}$ mixture consisting of $10 \times$ MIX (USB), $2.5 \mathrm{mM} \mathrm{MgCl}{ }_{2}, 5 \mathrm{pmol}$ biotinylated primer, $10 \mathrm{pmol}$ non-biotinylated primer, $0 \cdot 2 \mathrm{nmol}$ each of the four NTPs and $2.5 \mathrm{U}$ Taq DNA polymerase (USB). Amplification was carried out in a thermocycler (GeneAmp RCP System 2400; Perkin Elmer) and initiated by 2 min denaturation at $94^{\circ} \mathrm{C}$ and then followed by 35 cycles, each cycle consisting of $30 \mathrm{~s}$ denaturation at $94{ }^{\circ} \mathrm{C}, 1 \mathrm{~min}$ annealing at $55^{\circ} \mathrm{C}$ and $2 \mathrm{~min}$ extension at $72{ }^{\circ} \mathrm{C}$. The solution was left at $72^{\circ} \mathrm{C}$ for 7 min after the last cycle.

Oligonucleotides were synthesized according to sequences and positions reported by Paster \& Dewhirst (1988) and Dewhirst et al. (1992) (Table 3). For the PCR amplification, one of the oligonucleotide primers was labelled with biotin (HPLC-purified; Pharmacia Biotech). This allowed DNA strand separation and purification of amplified DNA using streptavidin-coated magnetic beads (Dynabeads M-280) to trap the biotin-labelled PCR fragments. DNA strand separation was performed as recommended by the manufacturer. Briefly, the double-stranded DNA bound to the magnetic beads was incubated in $0 \cdot 1 \mathrm{M} \mathrm{NaOH}$ for $5 \mathrm{~min}$, allowing the non-biotinylated strand to be removed. After neutralization of the solution containing the nonbiotinylated strand, and additional washings of the bead fraction, both strands could be used as templates for DNA sequencing.

Sequencing was performed by the dideoxy chain-termination method (Sanger et al., 1977) using Autoread Sequencing Kit (Pharmacia Biotech) set up with $10 \mathrm{ng}$ fluorescein labelled primers using 3 U T7 DNA polymerase (Pharmacia Biotech) and 1-2 $\mathrm{gg}$ DNA template. Sequence reactions were analysed on the ALF Automatic DNA Sequencer (Pharmacia Biotech). For all strains 1467 bases were sequenced in both directions between positions 26 and 1492 according to the type strain of $[P$.] haemolytica (GenBank no. M75080).

Analysis of sequence data. Sequences were aligned manually to the 16S sequence of Escherichia coli (GenBank J01695) published by Brosius et al. (1978) and the consensus sequence given by Lane (1991). For alignment of the 16S rRNA sequences of strains R19.2, HPA121 and the GenBank sequence U57072 to other sequences, one base (guanine) at position 1126 ( $E$. coli position 1135 ) was removed. Maximum-likelihood analysis and bootstrap analysis (100 repeats) were performed by fastDNAml (Olsen et al., 1994) run on a HP9000/819 computer. Similarities within and between the clusters obtained were calculated as the mean similarity between all pairs of sequences transformed to evolutionary distances by accounting for superimposed nucleotide substitutions by the method of Jukes \& Cantor (1969).

GenBank accession numbers. The GenBank accession numbers for the $16 \mathrm{~S}$ rRNA sequences of the strains examined are listed in Table 1.

Preparation of DNA for DNA-DNA hybridization. Cells were grown under shaking at $37^{\circ} \mathrm{C}$ in Tryptic Soy Broth (Difco) supplemented with $0.4 \%(\mathrm{w} / \mathrm{v})$ filter-sterilized yeast extract (Oxoid) and $0.01 \mathrm{M} \mathrm{NaHCO}_{3}$. The cells were harvested in the early-stationary phase of growth, examined microscopically for purity, washed in $1 \times \mathrm{SSC}(0.15 \mathrm{M} \mathrm{NaCl}$ plus $0.015 \mathrm{M}$ trisodium citrate) and resuspended in $1 \times \mathrm{SSC}$ containing $0 \cdot 01 \mathrm{M}$ EDTA. High-molecular-mass DNA was isolated by combining the methods of Marmur (1961) and Kirby et al. (1967) as proposed by De Ley et al. (1970). Briefly, harvested cells were lysated at $60^{\circ} \mathrm{C}$ with SDS and treated with Pronase (Serva). DNA was isolated by repeated chloroform extractions and ethanol precipitations. After RNAase treatment, extraction with fenol/m-kresol was performed. DNA was then precipitated by m-kresol in $20 \%$ sodium-benzoate to remove carbohydrates. After dialysis in $0 \cdot 1 \times \mathrm{SSC}$, the DNA solution was treated with potassiumphosphate and 2-methoxyethanole to remove lipids. DNA 
Table 1. Strains investigated by $16 \mathrm{~S}$ rRNA sequencing

ATCC, American Type Culture Collection, Manassas, VA, USA; CCM, Czech Collection of Microorganisms, Brno, Czech Republic; CCUG, Culture Collection, University of Gothenburg, Sweden; NCTC, National Collection of Type Cultures, Colindale, UK.

\begin{tabular}{|c|c|c|c|}
\hline $\begin{array}{l}\text { GenBank } \\
\text { accession no. }\end{array}$ & Strain & Taxon* & Source \\
\hline AF060699 & NCTC $9380^{\mathrm{T}}$ & {$[P$.$] haemolytica biogroup 1$} & Ovine isolate \\
\hline AF053887 & UT26 & {$[P$.$] haemolytica biogroup 1$} & Ovine isolate \\
\hline AF053888 & P731 & {$[P$.] haemolytica biogroup $3 \mathrm{~A}$} & Ovine nose \\
\hline AF053889 & $\mathrm{P} 925^{\mathrm{T}}$ & [P.] haemolytica biogroup 3B & Ovine lung \\
\hline AF053890 & UT18 & {$[P$.$] haemolytica biogroup 3 \mathrm{C}$} & Ovine isolate \\
\hline AF053891 & P737 & {$[P$.$] haemolytica biogroup 3 \mathrm{G}$} & Ovine nose \\
\hline AF053892 & P733 & {$[P$.$] haemolytica biogroup 3 \mathrm{H}$} & Ovine nose \\
\hline AF053893 & $177^{\mathrm{T}}$ & {$[P$.$] haemolytica biogroup 6$} & Bovine pneumonia \\
\hline AF053894 & $\mathrm{R} 19.2$ & {$[P$.$] haemolytica biogroup 7$} & Bovine rumen \\
\hline AF053895 & HPA102 & {$[P$.$] haemolytica biogroup 8 \mathrm{~A}$} & Ovine rumen \\
\hline AF053896 & HPA98 & {$[P$.$] haemolytica biogroup 8D$} & Ovine rumen \\
\hline AF053897 & P730 & {$[P$.$] haemolytica biogroup 9$} & Ovine nose \\
\hline AF053898 & HPA121 & {$[P$.$] haemolytica biogroup 10$} & Bovine rumen \\
\hline AF053899 & CCM $5786(=$ F155) & Bisgaard taxon 15 biovar 1 & Pig sepsis \\
\hline AF053900 & HPA92 $^{\mathrm{T}}$ & Bisgaard taxon 18 biovar 1 & Ovine rumen \\
\hline AF053901 & $\mathrm{Ph} 13$ & Bisgaard taxon 20 biovar 1 & Hare lung \\
\hline AF053902 & ATCC $49244^{\mathrm{T}}$ & Pasteurella granulomatis & Bovine panniculitis \\
\hline \multicolumn{4}{|c|}{ Sequences from GenBank included in maximum-likelihood analysis } \\
\hline M75080 & NCTC $9380^{\mathrm{T}}, \mathrm{PH} 208$, PH380 & {$[P$.$] haemolytica serotype 2$} & Ovine isolates \\
\hline U57066 & $\begin{array}{l}\text { PH2, PH8, PH66, PH236, РH284, } \\
\text { PH296, РH344,PH374, PH376, } \\
\text { PH388,PH568, PH570, PH706, UT3 }\end{array}$ & $\begin{array}{c}{[P .] \text { haemolytica serotypes } 1} \\
5-9,12-14,16 \text { and } U G 1 \dagger\end{array}$ & $\begin{array}{l}\text { Bovine and ovine } \\
\text { isolates }\end{array}$ \\
\hline U57067 & PH344 & {$[P$.$] haemolytica serotype 11$} & Ovine isolate \\
\hline U57068 & PH152 & {$[P$.$] haemolytica \mathrm{UG} 3 \dagger$} & Bovine pneumonia \\
\hline U57069 & PH290 & {$[P$.$] haemolytica \mathrm{UG} 3 \dagger$} & Ovine abortion \\
\hline U57070 & PH40 (= UT35) & {$[P$.$] haemolytica \mathrm{UG} 4 \dagger$} & Bovine pneumonia \\
\hline U57071 & PH360 & {$[P$.$] haemolytica \mathrm{UG} 4 \dagger$} & Bovine liver \\
\hline U57072 & PH704 & {$[P$.$] haemolytica UG5†$} & Bovine abortion \\
\hline U57075 & NCTC 10626 & {$[P$.$] trehalosi serotype T4$} & Ovine isolate \\
\hline U57076 & CCUG $16500(=\mathrm{F} 454)$ & Bisgaard taxon 15 biovar 1 & Pig pneumonia \\
\hline U57077 & CCUG 20954 (= HPA81) & Bisgaard taxon 18 biovar 1 & Ovine rumen \\
\hline U57078 & CCUG $16505 \ddagger$ & Bisgaard taxon 20 & Rabbit isolate \\
\hline M75062 & NCTC $11408^{\mathrm{T}}$ & Actinobacillus capsulatus & Rabbit arthritis \\
\hline M59769 & NCTC $10322^{\mathrm{T}}$ & Pasteurella multocida & Bovine isolate \\
\hline M75068 & NCTC $4189^{\mathrm{T}}$ & Actinobacillus lignieresii & Bovine granuloma \\
\hline M59433 & NCTC $8143^{\mathrm{T}}$ & Haemophilus influenzae & Human \\
\hline
\end{tabular}

* Taxa according to Angen et al. (1997a, b).

† Untypable groups according to Davies et al. (1996).

¥According to Davies et al. (1996), U57078 refers to CCUG 16504. However, this is not a taxon 20 strain. According to a personal communication between Curator E. Falsen, CCUG, and M. Bisgaard of 16 September 1996, CCUG 16505 was sent to Dr I. Olsen. This means that CCUG 16504 should be replaced by CCUG 16505.

was then repeatedly precipitated with ethanol and dialysed against $0 \cdot 1 \times$ SSC. Only high-molecular-mass DNA that could be spun up on a glass rod was used for hybridizations. DNA-DNA hybridization. Initial renaturation rates of homologous or heterologous solutions of DNA were determined by the method of De Ley et al. (1970), using a model 250 spectrophotometer (Gilford Instruments). A DNA concentration of $80 \mu \mathrm{g} \mathrm{ml}^{-1}$, a salt milieu containing $2 \times \mathrm{SSC}$, and a reassociation temperature of $68^{\circ} \mathrm{C}$ were used. The reassociation temperature was calculated as proposed by Gillis et al. (1970). The DNA binding values (D\%) were calculated according to the formula given by De Ley et al. (1970). Each experiment was repeated at least three times.

Determination of $\mathbf{G}+\mathbf{C}$ content of the DNA. $\mathrm{G}+\mathrm{C}$ contents of the DNA preparations were determined from thermal 
Table 2. Origin and $\mathrm{G}+\mathrm{C}$ content of strains investigated by DNA-DNA hybridization

\begin{tabular}{|c|c|c|c|c|c|}
\hline Strain & CCUG no. & Taxon* & New name & Source & $\begin{array}{c}\mathrm{G}+\mathrm{C} \mathrm{mol} \mathrm{\%} \\
\text { (SD) }\end{array}$ \\
\hline NCTC $9380^{\mathrm{T}}$ & 12392 & {$[P$.$] haemolytica biogroup 1$} & M. haemolytica & Ovine isolate & $43 \cdot 6(0 \cdot 1)$ \\
\hline 265 & 38454 & [P.] haemolytica biogroup 1 & M. haemolytica & Bovine pneumonia & - \\
\hline UT26 & 38455 & {$[P$.$] haemolytica biogroup 1$} & $\dagger$ & Ovine isolate & $42 \cdot 6(0 \cdot 1)$ \\
\hline P731 & 38456 & {$[P$.$] haemolytica biogroup 3 \mathrm{~A}$} & M. glucosida & Ovine nose & $43 \cdot 2(0 \cdot 5)$ \\
\hline $\mathrm{P} 925^{\mathrm{T}}$ & 38457 & {$[P$.$] haemolytica biogroup 3B$} & M. glucosida & Ovine lung & $41 \cdot 6(0 \cdot 1)$ \\
\hline UT18 & 38458 & {$[P$.$] haemolytica biogroup 3 \mathrm{C}$} & M. glucosida & Ovine isolate & $41 \cdot 8(0 \cdot 1)$ \\
\hline P737 & 38459 & {$[P$.$] haemolytica biogroup 3 \mathrm{G}$} & M. glucosida & Ovine nose & $43 \cdot 5(0 \cdot 2)$ \\
\hline P733 & 38460 & {$[P$.$] haemolytica biogroup 3 \mathrm{H}$} & M. glucosida & Ovine nose & $42 \cdot 7(0 \cdot 2)$ \\
\hline W4672/1 & 38461 & {$[P$.$] haemolytica biogroup 3 \mathrm{~J}$} & M. granulomatis & Bovine tongue & - \\
\hline $177^{\mathrm{T}}$ & 38462 & {$[P$.$] haemolytica biogroup 6$} & M. varigena & Bovine pneumonia & $41 \cdot 7(0 \cdot 1)$ \\
\hline $\mathrm{R} 19.2$ & 38463 & {$[P$.$] haemolytica biogroup 7$} & $\dagger$ & Bovine rumen & - \\
\hline HPA102 & 38464 & {$[P$.$] haemolytica biogroup 8 \mathrm{~A}$} & $\dagger$ & Ovine rumen & $40 \cdot 0(0 \cdot 4)$ \\
\hline M14.4 & 38465 & {$[P$.$] haemolytica biogroup 8 \mathrm{C}$} & $\dagger$ & Bovine mouth & - \\
\hline HPA98 & 38466 & [P.] haemolytica biogroup 8D & M. ruminalis & Ovine rumen & - \\
\hline P730 & 38467 & {$[P$.$] haemolytica biogroup 9$} & M. glucosida & Ovine nose & $43 \cdot 9(0 \cdot 3)$ \\
\hline HPA121 & 38468 & {$[P$.$] haemolytica biogroup 10$} & $\dagger$ & Bovine rumen & $40 \cdot 2(0 \cdot 4)$ \\
\hline UT27 & 38469 & {$[P$.$] haemolytica biogroup 10$} & $\dagger$ & Ovine isolate & $43 \cdot 7(0 \cdot 2)$ \\
\hline HPA92 $^{\mathrm{T}}$ & 38470 & Bisgaard taxon 18 biovar 1 & M. ruminalis & Ovine rumen & - \\
\hline HPA109 & 38471 & Bisgaard taxon 18 biovar $3, x y$ lose $e^{-}$ & $M$. ruminalis & Ovine rumen & - \\
\hline P655 & 38472 & Bisgaard taxon 15 biovar 1 & M. varigena & Porcine sepsis & $41 \cdot 4(0 \cdot 1)$ \\
\hline P411 & 38473 & Bisgaard taxon 20 biovar 1 & M. granulomatis & Rabbit isolate & $40 \cdot 8(0 \cdot 5)$ \\
\hline Ph13 & 26828 & Bisgaard taxon 20 biovar 1 & M. granulomatis & Hare lung & - \\
\hline BJ1680.3 & 38474 & Bisgaard taxon 20 biovar 2 & M. granulomatis & Hare isolate & - \\
\hline H39 & 38475 & Bisgaard taxon 36 & M. varigena & Bovine mastitis & - \\
\hline ATCC $49244^{\mathrm{T}}$ & - & P. granulomatis & M. granulomatis & Bovine panniculitis & $39 \cdot 2(2 \cdot 1)$ \\
\hline NCTC $11408^{\mathrm{T}}$ & 12396 & A. capsulatus & & Hare arthritis & - \\
\hline NCTC 10624 & - & {$[P$.$] trehalosi serotype \mathrm{T} 15$} & & Ovine isolate & $42 \cdot 6$ \\
\hline
\end{tabular}

* Taxa according to Angen et al. (1997a, b).

$\dagger$ Unnamed species in Mannheimia.

Table 3. Oligonucleotide primers used for PCR amplification and sequencing of $16 \mathrm{~S}$ rRNA

\begin{tabular}{|cllcl|}
\hline $\begin{array}{l}\text { Primer } \\
\text { no. }\end{array}$ & \multicolumn{1}{c}{ Type } & \multicolumn{1}{c|}{ Sequence $\left(\mathbf{5}^{\prime} \rightarrow \mathbf{3}^{\prime}\right)^{*}$} & Position ${ }^{\dagger}$ & Orientation \\
\hline 1 & PCR biotinylated & B-AGAGTTTGATYMTGGCT & $8-24$ & Forward \\
2 & PCR & TACGGYTACCTTGTTACGACT & $1493-1513$ & Reverse \\
3 & Sequencing & F-AGAGTTTGATYMTGGCT & $8-24$ & Forward \\
4 & Sequencing & F-ACTGCTGCCTCCCGT & $344-358$ & Reverse \\
5 & Sequencing & F-ACGGGAGGCAGCAGT & $344-358$ & Forward \\
6 & Sequencing & F-CTACCAGGGTATCTAATC & $786-803$ & Reverse \\
7 & Sequencing & F-GATTAGATACCCTGGTAG & $786-803$ & Forward \\
8 & Sequencing & F-GGTTGCGCTCGTTGCGGG & $1096-1113$ & Reverse \\
9 & Sequencing & F-CCCGCAACGAGCGCAACC & $1096-1113$ & Forward \\
10 & Sequencing & F-TACGGYTACCTTGTTACGACT & $1493-1513$ & Reverse \\
\hline
\end{tabular}

* Y, C or T; M, A or C; B, biotin; F, fluorescein.

$\dagger$ Numbers according to $E$. coli positions (Brosius et al., 1978).

denaturation midpoints $\left(T_{\mathrm{m}}\right)$ (Marmur \& Doty, 1962) and were calculated according to De Ley et al. (1970).

Analysis of hybridization data. Single linkage clustering (Sneath \& Sokal, 1973) was performed on the matrix of Dvalues using the taxonomy program NTSYs (Rohlf, 1993).
Comparison of 16S rRNA sequence similarities and DNA binding levels. For 78 pairs of strains both DNA reassociation values and 16S rRNA sequences were available. A plot of the sequence similarities [Jukes \& Cantor (1969) corrected] against the DNA binding levels and 
standard deviations was performed using Fig.P version 2.7 (BIOSOFT).

\section{RESULTS}

\section{Phylogenetic analysis by 165 rRNA comparison}

The result of the maximum-likelihood analysis of the $16 \mathrm{~S}$ rRNA sequences is shown in Fig. 1. The trehalose- negative $[P$.$] haemolytica complex formed five distinct,$ but affiliated clusters, indicated by numerals I-V. The mean sequence differences within each cluster ranged from 0.9 to $2.5 \%$ (Table 4 ). The mean sequence differences between the five clusters ranged from $2 \cdot 8$ to $4.4 \%$, clusters I + II $(2.9 \%)$ and IV + V $(2.8 \%)$ being the most affiliated ones.

The significance of the phylogenetic analysis was

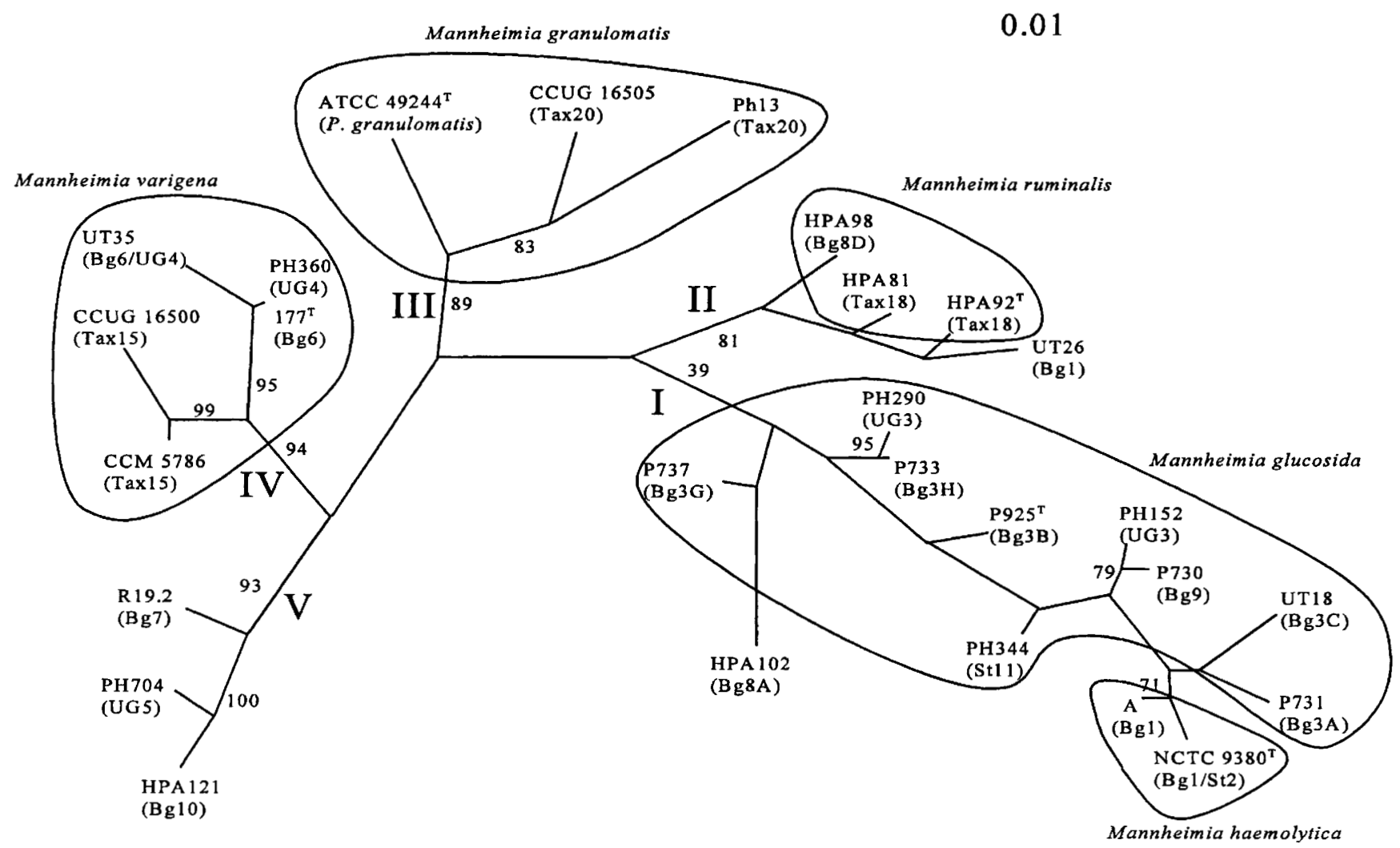

Fig. 1. Phylogenetic relationships within the [P.] haemolytica complex as revealed by maximum-likelihood analysis of $16 \mathrm{~S}$ rRNA sequences. Five major clusters are indicated as well as the five proposed species within Mannheimia. The boundaries of the new species are only indicative as some of the strains (PH152, PH290, PH344, PH360) have only been investigated by $16 \mathrm{~S}$ rRNA sequencing. Bg, Biogroup of $[P$.] haemo/ytica; Tax, Bisgaard taxon; St, serotype; UG, untypable group; $A$, sequence representing serotypes $1,5-9,12-14,16$ and $U G 1$. Numbers adjacent to branches indicate how often (out of 100 repeats) the clusters and strains branched together in bootstrap analyses.

Table 4. Mean 16S rRNA sequence differences within and between 165 rRNA clusters of the trehalose-negative $[P$.] haemolytica complex

16SrRNA clusters are according to Fig. 1. Values are Jukes-Cantor corrected distances as $\%( \pm \mathrm{SD})$.

\begin{tabular}{|lrrrrrr|}
\hline Cluster & I & II & I + II & III & IV & V \\
\hline I & $1 \cdot 4( \pm 0 \cdot 5)$ & & & & & \\
II & $2 \cdot 9( \pm 1 \cdot 2)$ & $2 \cdot 2( \pm 1 \cdot 3)$ & & & & \\
I + II & - & - & $2 \cdot 0( \pm 1 \cdot 2)$ & & & \\
III & $3 \cdot 6( \pm 0 \cdot 4)$ & $4 \cdot 4( \pm 1 \cdot 1)$ & $3 \cdot 7( \pm 0 \cdot 6)$ & $2 \cdot 5( \pm 0 \cdot 3)$ & & \\
IV & $4 \cdot 3( \pm 0 \cdot 4)$ & $4 \cdot 2( \pm 1 \cdot 0)$ & $4 \cdot 2( \pm 0 \cdot 6)$ & $3 \cdot 7( \pm 0 \cdot 4)$ & $1 \cdot 6( \pm 0 \cdot 9)$ & \\
V & $3 \cdot 7( \pm 0 \cdot 3)$ & $3 \cdot 8( \pm 1 \cdot 0)$ & $3 \cdot 8( \pm 0 \cdot 6)$ & $3 \cdot 6( \pm 0 \cdot 2)$ & $2 \cdot 8( \pm 0 \cdot 4)$ & $0 \cdot 9( \pm 0 \cdot 4)$ \\
\hline
\end{tabular}




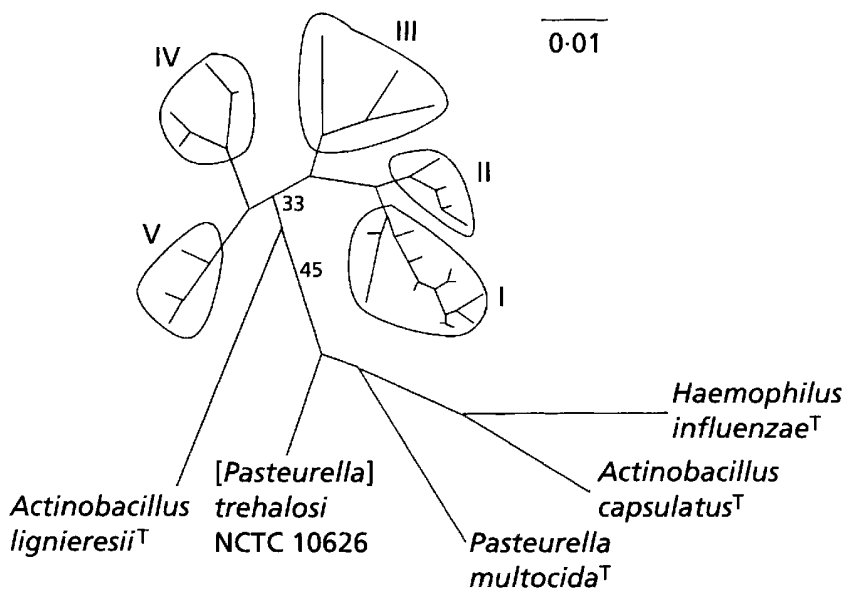

Fig. 2. Phylogenetic relationships between the five clusters representing the [P.] haemolytica complex and selected reference strains of the family Pasteurellaceae as revealed by maximum-likelihood analysis of $16 \mathrm{~S}$ rRNA sequences.

assessed by bootstrap analysis. The numbers above the branches in Fig. 1 indicate how often (in \%) the clusters were found as monophyletic groups. Clusters II-V were found as monophyletic in more than $80 \%$ of the repeats, whereas the sequences in cluster I only clustered together in $39 \%$ of the repeats. Three pairs of sequences within cluster I clustered together in more than $50 \%$ of the repeats (indicated in Fig. 1).

Cluster I contained the type strain of $[P$.] haemolytica (biogroup 1). The sequence found was identical to the sequence found by Davies et al. (1996), but differed at 18 positions from a GenBank sequence having the same accession number and downloaded in 1995 (14 of these differences due to Ns). The closest affiliated sequence to that of the type strain was sequence U57066 (designated A in Fig. 1) which was common for serotypes 1, 5-9, 12-14, 16 and untypable group 1 (UG1), differing in two nucleotide positions. These two sequences clustered together in $71 \%$ of the bootstrap trees. The other strains found within cluster I represent biogroups 3A, 3B, 3C, 3G, 3H, $8 \mathrm{~A}$ and 9 of
$[P$.$] haemolytica (Angen et al., 1997a) and Davies'$ sequences representing UG3 and serotype 11 (Davies et al., 1996). From Fig. 1 it can be seen that although the different sub-groups of biogroup 3 are found within the same $16 \mathrm{~S}$ rRNA cluster, their sequences differ considerably, and they do not constitute a separate phylogenetic branch in the tree. Furthermore, they do not form a separate branch in any of the 100 bootstrap analyses performed. Cluster II consisted of four strains representing biogroup $8 \mathrm{D}$ of $[P$.] haemolytica, Bisgaard taxon 18 biovar 1 and a strain of biogroup 1 (UT26). Cluster III contained representatives of $P$. granulomatis and Bisgaard taxon 20. Cluster IV consisted of strains representing Bisgaard taxon 15 and biogroup 6 of $[P$.] haemolytica, in addition to representatives of Davies' untypable group 4 (UG4). One UG4 strain had a 16S rRNA sequence identical to strain 177 of biogroup 6. Cluster V contained representatives of biogroups 7 and 10 of $[P$.] haemolytica as well as a strain representing Davies' untypable group 5 (UG5).

A maximum-likelihood analysis including selected reference strains within the family Pasteurellaceae is shown in Fig. 2. The five clusters of $[P$. $]$ haemolytica had a common root relative to all these strains. In the bootstrap analysis the five clusters were found as monophyletic in $33 \%$ of the repeats. The five clusters including Actinobacillus lignieresii had a common branching relative to the other taxa investigated in $45 \%$ of the repeats. $[P$.] trehalosi joined this group in $28 \%$ of the repeats, and Pasteurella multocida in $13 \%$ of the repeats. The mean distances between strains of the trehalose-negative $[P$.] haemolytica complex and the selected reference strains are shown in Table 5. The trehalose-negative $[P$.] haemolytica complex is most closely related to genus Actinobacillus as evaluated by the distances to the type species of the three old genera. The mean sequence difference between all pairs of sequences within all five clusters was $3 \cdot 1 \%(\mathrm{SD}=1 \cdot 3)$. Based on the type strains of the species belonging to the genera Actinobacillus and Pasteurella as defined by DNA-DNA hybridizations (Mutters et al., 1989) the mean 16S rRNA sequence difference within genus Actinobacillus sensu stricto was $5 \cdot 0 \%(\mathrm{SD}=2 \cdot 3)$ and

Table 5. Mean differences of 16S rRNA sequences between the trehalose-negative [P.] haemolytica complex and reference strains within the family Pasteurellaceae

\begin{tabular}{|c|c|c|c|c|}
\hline & $\begin{array}{c}{[P .] \text { haemolytica }} \\
\text { complex* }\end{array}$ & {$[P$.$] trehalosi \dagger$} & A. lignieresï ${ }^{\mathrm{T}}$ & P. multocida ${ }^{\mathrm{T}}$ \\
\hline$[P$.$] haemolytica complex$ & $3 \cdot 1( \pm 1 \cdot 3)$ & & & \\
\hline P. trehalosi & $5 \cdot 0( \pm 0 \cdot 6)$ & $0.9( \pm 0.4)$ & & \\
\hline A. lignieresii $^{\mathrm{T}}$ & $5.5( \pm 0.6)$ & $6 \cdot 3( \pm 0 \cdot 1)$ & - & \\
\hline P. multocida ${ }^{\mathrm{T}}$ & $7 \cdot 5( \pm 0 \cdot 7)$ & $6 \cdot 0( \pm 0 \cdot 1)$ & $7 \cdot 5$ & - \\
\hline H. influenzae $e^{T}$ & $7 \cdot 7( \pm 0 \cdot 5)$ & $7 \cdot 2( \pm 0 \cdot 2)$ & $8 \cdot 0$ & $6 \cdot 5$ \\
\hline
\end{tabular}

* Including all 16S rRNA clusters according to Figs 1 and 2.

$\dagger$ Including representatives of the four serotypes, NCTC 11550, NCTC 10641, NCTC 10624 and NCTC 10626. 


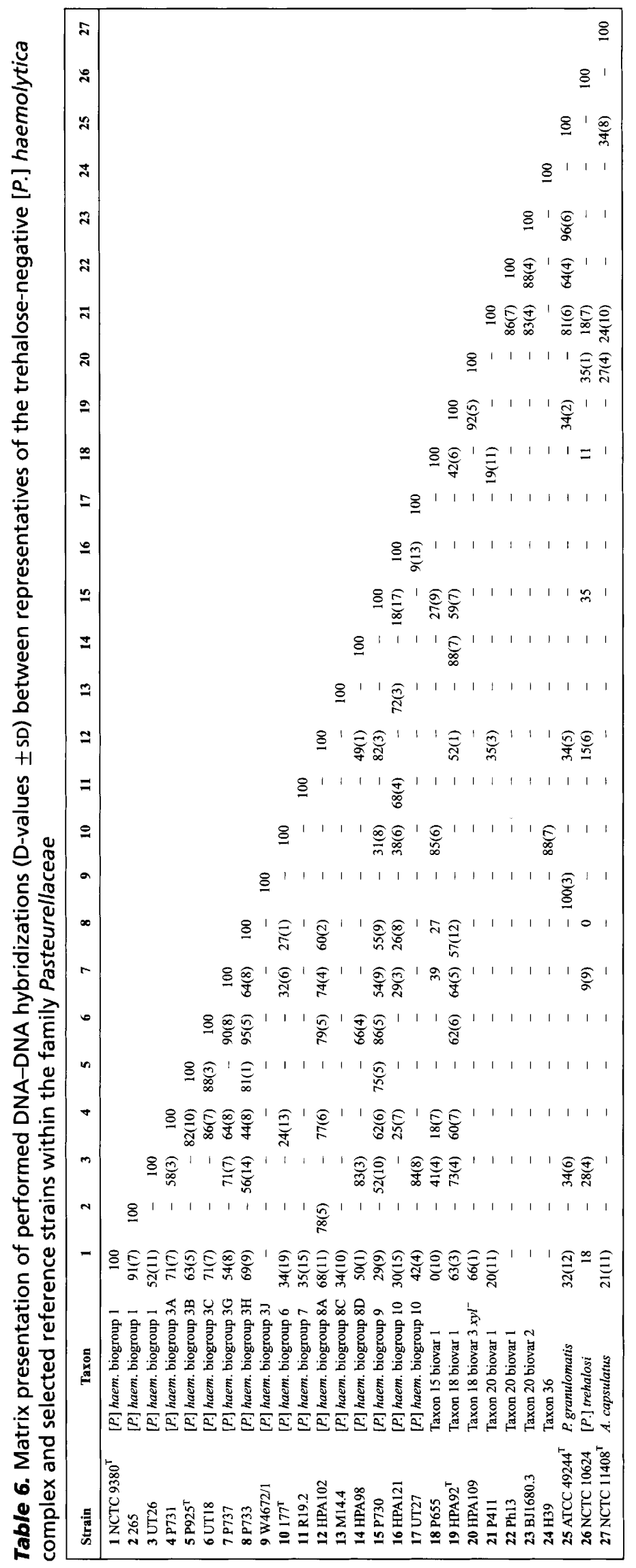




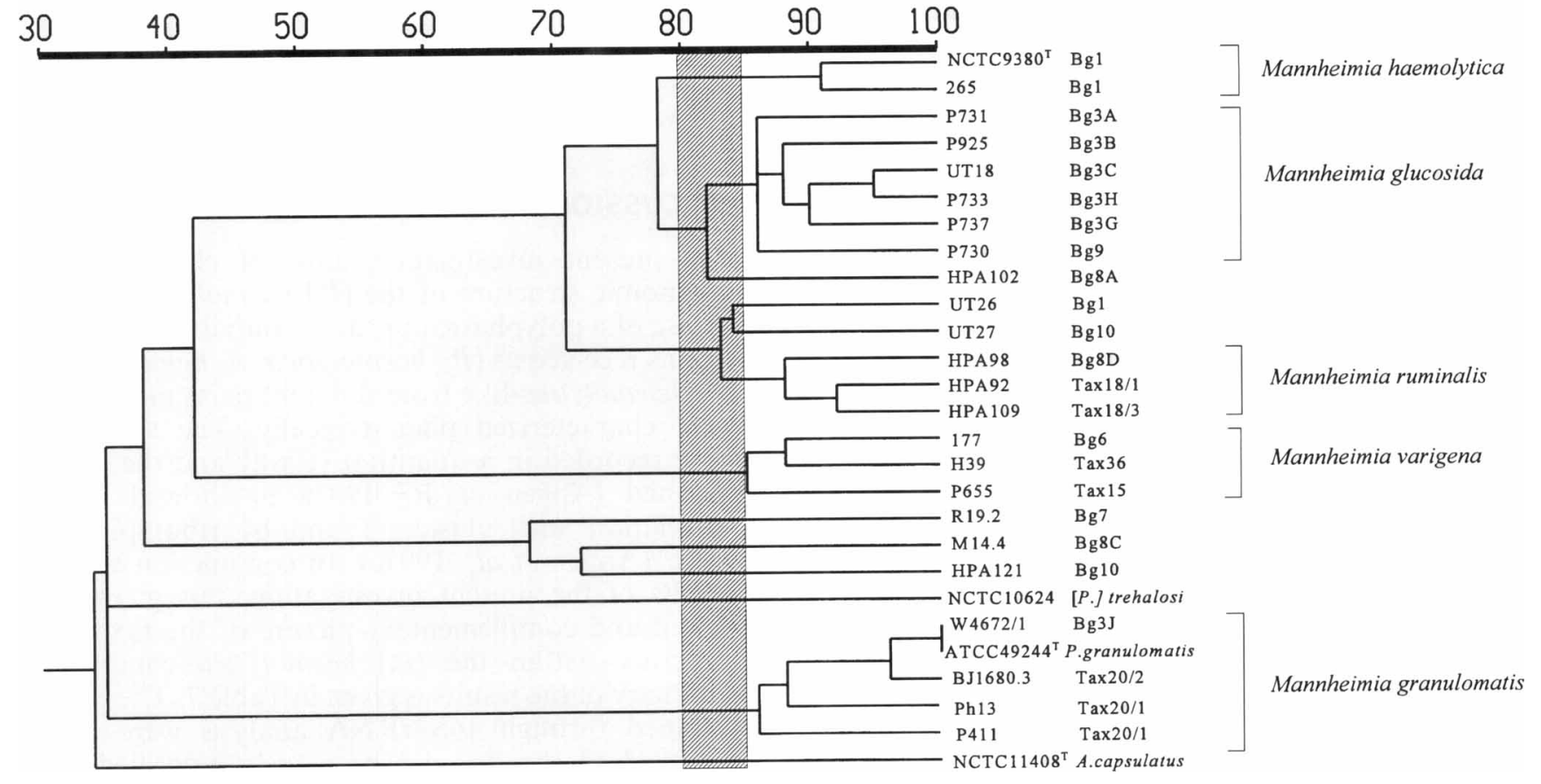

Fig. 3. Single-linkage clustering of DNA binding values within the $[P$.$] haemolytica complex. Brackets indicate strains$ which cluster above $85 \%$ DNA binding. Area at 80-85\% DNA binding is indicated by the box.

within genus Pasteurella sensu stricto was $7 \cdot 0 \%$ (SD $=$ $2 \cdot 5$ ). For comparison, the mean sequence difference between the five new species proposed in the present investigation was $2.7 \%(\mathrm{SD}=0 \cdot 8)$. The mean sequence difference between one representative from each of the five 16S rRNA clusters (NCTC $9380^{\mathrm{T}}$, HPA $92^{\mathrm{T}}$, ATCC $49244^{\mathrm{T}}, 177^{\mathrm{T}}$ and HPA 121$)$ was $3 \cdot 4 \%(\mathrm{SD}=$ $0 \cdot 6)$.

\section{$\mathbf{G}+\mathbf{C}$ content}

The $\mathrm{G}+\mathrm{C}$ contents of the strains investigated are shown in Table 2 . The values for the $[P$.] haemolytica complex ranged from $39 \cdot 2-43 \cdot 9 \mathrm{~mol} \%$. A correlation between the $\mathrm{G}+\mathrm{C}$ content and the clusters outlined through the 16S rRNA sequence analysis was not observed.

\section{DNA-DNA hybridizations}

DNA-DNA hybridizations have been performed between 102 pairs of strains. The DNA binding values $(\mathrm{D} \%)$ and the standard deviations of the experiments are presented as a matrix in Table 6. A dendrogram based upon single linkage clustering of the $\mathrm{D}$-values is shown in Fig. 3.

The type strain of $[P$.$] haemolytica \left(\right.$ NCTC $9380^{\mathrm{T}}$ ) clustered above $70 \%$ with strains representing biogroups $3 \mathrm{~A}, 3 \mathrm{~B}, 3 \mathrm{C}, 3 \mathrm{G}, 3 \mathrm{H}, 8 \mathrm{~A}, 9$ and 10 of $[P$. haemolytica, and strains representing biovars 1 and 3 of Bisgaard taxon 18. A DNA binding of $52 \%$ was observed with strain UT26, which shares the phenotypical characters of biogroup 1 (Angen et al., 1997a).
NCTC $9380^{\mathrm{T}}$ showed DNA binding of $91 \%$ with strain 265 from biogroup 1. Strain 265 was the most deviating strain within the ribotype cluster containing the type strain (Angen et al., 1997c).

The strains representing biogroups $3 \mathrm{~A}, 3 \mathrm{~B}, 3 \mathrm{C}, 3 \mathrm{G}, 3 \mathrm{H}$ and 9 of $[P$.] haemolytica clustered above $85 \%$ by single linkage. Strain UT18 (biogroup 3C) showed DNA bindings at or above $86 \%$ with all other strains in this group against which it was tested. On the other hand, strains P731 (biogroup 3A) and P733 (biogroup $3 \mathrm{H}$ ) only showed DNA binding of $44 \%$. The group as such clustered with the type strain at a DNA binding level of $71 \%$. Biogroup 8A (strain HPA102) showed high affiliation to this group with DNA binding values in the range $52-79 \%$. All strains investigated in $16 \mathrm{~S}$ rRNA cluster I (NCTC 9380 ${ }^{\mathrm{T}}$, P731, P925, UT18, P733, P737, P730 and HPA102) were linked at DNA binding of $78 \%$.

The two strains representing Bisgaard taxon 18 biovars 1 and 3 showed DNA binding of $92 \%$ and clustered with $[P$.] haemolytica biogroup $8 \mathrm{D}$ at $88 \%$. Strain UT26 (biogroup 1) showed DNA binding of $83 \%$ with strain HPA98 ([P.] haemolytica biogroup 8D) and $84 \%$ with strain UT27 ([P.] haemolytica biogroup 10), respectively. All strains in 16S rRNA cluster II investigated (UT26, HPA92 and HPA98) were linked at DNA binding of $83 \%$. The strains of $16 \mathrm{~S}$ rRNA clusters I and II were linked at a DNA binding level of $70 \%$.

The type strain of $P$. granulomatis and three strains representing Bisgaard taxon 20 biovars $1(\mathrm{Ph} 13$ and P411) and 2 (BJ1680.3) linked at a DNA binding level 


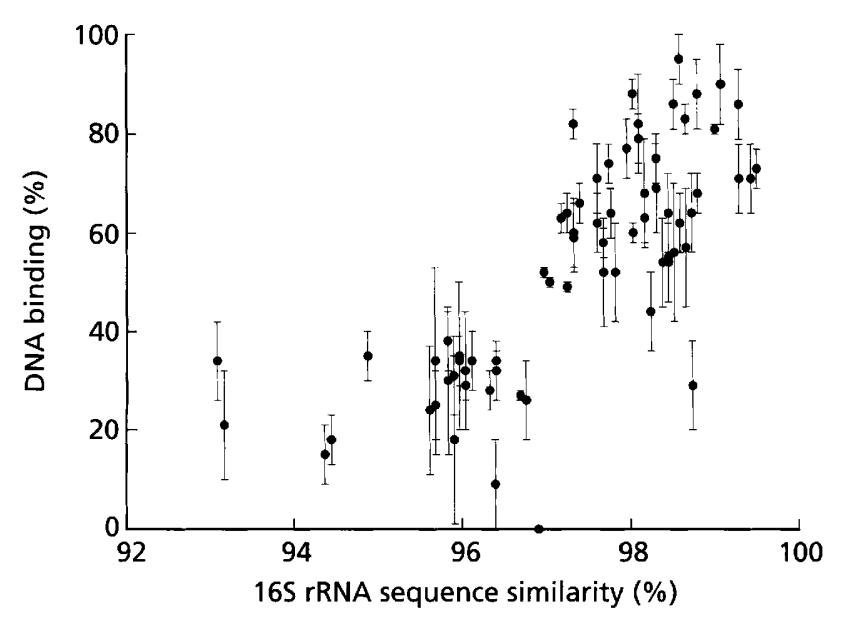

Fig. 4. Plot of corresponding $16 \mathrm{~S}$ rRNA sequence similarities and DNA binding values for 78 pairs of strains within the $[P$. haemolytica complex. Vertical lines indicate the standard deviations of the DNA reassociation experiments.

of $86 \%$. Additionally, $100 \%$ DNA binding was found between strain W4672/1 representing [P.] haemolytica biogroup $3 \mathrm{~J}$ and $P$. granulomatis. This group represents taxa found in the 16S rRNA cluster III.

$[P$.] haemolytica biogroup 6, Bisgaard taxon 15 biovar 1 and Bisgaard taxon 36 were linked at $85 \%$ DNA binding. These taxa corresponded to those found in $16 \mathrm{~S}$ rRNA cluster IV.

Three strains representing $[P$.] haemolytica biogroups $7,8 \mathrm{C}$ and 10 showed DNA binding in the range 68-72\%. Two of these strains (R19.2 and HPA121) were also investigated by $16 \mathrm{~S}$ rRNA sequencing and were located in cluster V. Biogroup 10 of $[P$.] haemolytica was, however, genetically heterogeneous as DNA binding of only $9 \%$ was found between strains HPA121 and UT27.

Strains representing 16 S rRNA clusters I+ II, III, IV and $\mathrm{V}$ showed DNA binding at or below $42 \%$. Approximately the same binding level was observed between representatives of these clusters and $[P$.] trehalosi and A. capsulatus.

\section{Correlation between DNA binding levels and 16S rRNA sequence similarity}

Fig. 4 shows a plot of 16S rRNA sequence similarities and the corresponding DNA binding levels between 78 pairs of strains. Two groups could be outlined in the plot. All pairs of strains having a sequence similarity below $97 \%$ had DNA binding of less than $40 \%$. The separation between these groups was less distinct when the standard deviation of the DNA reassociations was considered (Fig. 4). A positive correlation between the 16S rRNA sequences similarity and DNA binding value was observed. Using linear regression, the correlation coefficient was $0 \cdot 54$. A plot of the sequence similarities against the DNA binding levels obtained by single-linkage clustering separated the points of the plot in two clear groups as all $y$-values between 40 and $68 \%$ disappeared (data not shown), corresponding to the way the DNA binding data are presented in Fig. 3.

\section{DISCUSSION}

The present investigation aims at elucidating the taxonomic structure of the $[P$.] haemolytica complex by use of a polyphasic approach. Initially, a variety of strains received as $[P$.] haemolytica, $A$. lignieresii or as $[P$.] haemolytica-like from different parts of the world were characterized phenotypically. The test results were recorded in a quantitative way and the clusters outlined (Angen et al., 1997a, b) showed a clear correlation with clusters found by ribotyping and MEE (Angen et al., 1997c). In conjunction with the results of the present investigation, this gives a coherent and complementary picture of the taxonomic structure within the $[P$.] haemolytica complex. A summary of the results is given in Table 7 . The clusters outlined through $16 \mathrm{~S}$ rRNA analysis were almost identical to the lineages previously identified using MEE and ribotyping (Angen et al., 1997c). Cluster I corresponds to MEE lineage A, cluster II to lineage B, cluster III to lineage $\mathrm{F}$, cluster IV to lineage $\mathrm{C}$, while cluster $\mathrm{V}$ corresponds to lineages $\mathrm{D}$ and $\mathrm{E}$. Furthermore, DNA-DNA hybridizations have confirmed that taxa located in the different clusters (according to ribotyping, MEE or 16S rRNA sequencing) have high genetic affiliation. The overall correspondence noticed between results obtained using different methods allow us to draw conclusions from the polyphasic taxonomic investigation.

\section{Taxonomic position within the family Pasteurellaceae}

Maximum-likelihood analysis including the 16S rRNA sequences of the type strains of $A$. lignieresii, $P$. multocida, $H$. influenzae, $[P$.$] trehalosi and A$. capsulatus showed that these organisms were only distantly related to the trehalose-negative $[P$.] haemolytica complex (Fig. 2) underlining that a close affiliation to any of the recognized genera within the family Pasteurellaceae does not exist. The $[P$.] haemolytica complex, however, showed a higher affiliation to genus Actinobacillus than to genus Pasteurella, which is in accordance with previous investigations (Mraz, 1969; Mannheim, 1983; Mutters et al., 1986; Dewhirst et al., 1993; Davies et al., 1996).

The trehalose-negative strains of the $[P$.] haemolytica complex which have been dealt with in the present investigation are clearly different from trehalosepositive, but phenotypically affiliated taxa ([P.] trehalosi and $A$. capsulatus) both by $16 \mathrm{~S}$ rRNA sequencing and DNA-DNA hybridizations. Previously performed DNA hybridizations have indicated that [Pasteurella] testudinis might represent a genetic link between $[P$. $]$ trehalosi and the trehalosenegative $[P$.] haemolytica complex (Mutters et al., 
Table 7. Summary of results from a polyphasic investigation of the taxonomic structure within the trehalose-negative [Pasteurella] haemolytica complex reclassified as Mannheimia gen. nov.

Taxa are given according to Angen et al. (1997a, b). Ribotype cluster and MEE lineage according to Angen et al. (1997c). 16S rRNA cluster according to Fig. 1. According to Fig. 3, a DNA homology group is defined as strains clustering at a DNA binding level $\geq 85 \%$ by single linkage, thereby representing the same species; two groups of strains clustering above $60 \%$ are boxed. UC, Unclustered ; -, not investigated.

\begin{tabular}{|c|c|c|c|c|}
\hline Taxon & $\begin{array}{l}\text { Ribotype } \\
\text { cluster }\end{array}$ & $\begin{array}{c}\text { MEE } \\
\text { lineage }\end{array}$ & $\begin{array}{l}\text { 16S rRNA } \\
\text { cluster }\end{array}$ & $\begin{array}{c}\text { DNA homology } \\
\text { group }\end{array}$ \\
\hline$[P$.$] haemolytica biogroup 1$ & 1 & Al & I & M. haemolytica \\
\hline$[P$.$] haemolytica biogroup 3 \mathrm{~A}-3 \mathrm{H}$ and 9 & $4-11$ & A3-A6 & I & M. glucosida \\
\hline$[P$.$] haemolytica biogroup 8 \mathrm{~A}$ & 2 & A2 & I & $\mathrm{UC}$ \\
\hline$[P$.$] haemolytica biogroup 8 \mathrm{D}$ & 12 & B1 & II & M. ruminalis \\
\hline Bisgaard taxon 18 biovars 1 and 3 & $13+14$ & $\mathrm{~B}^{*}$ & II* & M. ruminalis \\
\hline [P.] haemolytica biogroup 1 (strain UT26) & $\mathrm{UC}$ & B & II & $\mathrm{uC}$ \\
\hline$[P$.$] haemolytica biogroup 10 \dagger$ & UC & $\mathrm{B}$ & - & $\mathrm{UC}$ \\
\hline Bisgaard taxon 15 biovars 1 and 2 & $15+16$ & $\mathrm{C} 1+\mathrm{C} 2 \ddagger$ & IV $\ddagger$ & M. varigena + \\
\hline$[P$.$] haemolytica biogroup 6$ & 15 & $\mathrm{C} 1+\mathrm{C} 3$ & IV & $M$. varigena \\
\hline Bisgaard taxon 36 & 15 & - & - & M. varigena \\
\hline Bisgaard taxon 20 biovars 1 and 2 & $18+19$ & $\mathrm{~F} 1+\mathrm{F} 2$ & III & M. granulomatis \\
\hline$[P$.$] haemolytica biogroup 3J$ & $3+19$ & - & - & M. granulomatis \\
\hline Pasteurella granulomatis & 3 & F3 & III & M. granulomatis \\
\hline$[P$.$] haemolytica biogroup 10$ & 17 & $\mathrm{D}+\mathrm{E}$ & $\mathrm{V}$ & $\mathrm{UC}$ \\
\hline [P.] haemolytica biogroup 7 & 17 & $\mathrm{D}$ & $\mathrm{V}$ & $\mathrm{UC}$ \\
\hline$[P$.$] haemolytica biogroup 8 \mathrm{C}$ & 17 & $\mathrm{D}$ & - & $\mathrm{UC}$ \\
\hline [P.] haemolytica biogroup $8 \mathrm{~B}$ and $9 \|$ & 17 & $\mathrm{D}$ & - & - \\
\hline
\end{tabular}

* Only taxon 18 biovar 1 investigated.

$\dagger 3$ out of the 10 investigated strains from biogroup 10 of $[P$. haemolytica found in these clusters.

† Only taxon 15 biovar 1 investigated.

$\S$ Only taxon 20 biovar 1 investigated.

I| meso-Inositol and NPG-negative strains of biogroup 9.

1986). 16S rRNA sequencing has, however, not confirmed this observation (Dewhirst et al., 1993). Further studies on the taxonomic relationships among these taxa are clearly indicated.

Presently great uncertainty seems to exist as to the taxonomic structure within the family Pasteurellaceae (Bisgaard, 1995). The delineation of the genera Pasteurella sensu stricto, Actinobacillus sensu stricto and Haemophilus sensu stricto has been based on DNA binding values, species showing more than $50 \%$ DNA binding having been included in the same genus. In 1989, 12 species were listed as Pasteurella sensu stricto while 10 species were listed as Actinobacillus sensu stricto and five species as Haemophilus sensu stricto (Mutters et al., 1989). According to the International Committee on Systematic Bacteriology Ad hoc committee on approaches to taxonomy within the Proteobacteria, genera should consist of taxa having a common phylogenetic origin and they should also be identified by phenotypic characters (Murray et al., 1990). Phenotypic separation of genera within the family Pasteurellaceae has, however, been difficult under the present conditions where the composition of genera has been based upon DNA-DNA hybridizations (Mutters et al., 1989). In recent publications new species within the family Pasteurellaceae tend to be allocated to Actinobacillus or Pasteurella more or less arbitrarily (Bisgaard, 1995), making phenotypic delineation between the genera increasingly difficult. Analysis of $16 \mathrm{~S}$ rRNA sequences within the family (Dewhirst et al., 1993) further complicated the taxonomic situation, as it was shown that the three genera delineated by DNA-DNA hybridization did not seem to represent separate phylogenetic lineages.

According to Dewhirst et al. (1993) accepted species of Pasteurella sensu stricto were located in three different 16S rRNA clusters: 3B (six species, including the type species $P$. multocida), 3A (four species) and 3D (two species). The 16S rRNA sequences of accepted Pasteurella spp. within clusters 3A, 3B and 3D differ on average by $2.4(\mathrm{SD}=0.5), 4.4(\mathrm{SD}=1.6)$ and $10 \%$, respectively. Cluster $3 \mathrm{~A}$ only contains taxa isolated from avian species whereas most of the taxa found in cluster $3 \mathrm{~B}$ are isolated from mammals. However, phenotypic separation of clusters $3 \mathrm{~A}$ and $3 \mathrm{~B}$ is not 
Table 8. Phenotypic characters separating the genera within the family Pasteurellaceae

Mannheimia results refer to Table 9. Actinobacillus data based on type strains of $A$. equuli, $A$. suis, A. ureae, A. pleuropneumoniae, A. hominis, A. lignieresii and Bisgaard taxon 8,9 and 11. Pasteurella data based on type strains of $P$. multocida, P. dagmatis, $P$. stomatis, $P$. canis, $P$. avium and Pasteurella sp. B. Haemophilus data based on $H$. influenzae, H. aegyptius, $H$. intermedius and $[H$.$] haemolyticus. Lonepinella data according to Osawa et al. (1995).$ + , Only positive reactions; - , only negative reactions; $\mathrm{d},+$ or - .

\begin{tabular}{|c|c|c|c|c|c|}
\hline Test & Mannheimia & Actinobacillus & Pasteurella & Haemophilus & Lonepinella \\
\hline Haemolysis & $\mathrm{d}$ & $\mathrm{d}$ & - & $\mathrm{d}$ & - \\
\hline V-factor dependency & - & $\mathrm{d}$ & $\mathrm{d}$ & + & - \\
\hline$X$-factor dependency & - & - & - & + & - \\
\hline VP, $37^{\circ} \mathrm{C}$ & - & - & - & - & + \\
\hline Urease & - & + & $\mathrm{d}$ & d & - \\
\hline $\begin{array}{l}\text { Ornithine } \\
\text { decarboxylase }\end{array}$ & $\mathrm{d}$ & - & d & d & - \\
\hline Indole & $-^{*}$ & - & $+\dagger$ & $\mathrm{d}$ & - \\
\hline L-Arabinose & $\mathrm{d}$ & $\mathrm{d}$ & - & - & $\mathrm{d}$ \\
\hline Glucosides $\ddagger$ & $\mathrm{d}$ & $\mathrm{d}$ & - & - & $\mathrm{d}$ \\
\hline Mannitol & + & d & $\mathrm{d}$ & - & - \\
\hline D-Mannose & - & $\mathrm{d}$ & + & $\mathrm{d}$ & Not known \\
\hline D-Melibiose & $-{ }^{*}$ & $\mathrm{~d}$ & - & - & $\mathrm{d}$ \\
\hline meso-Inositol & $\mathrm{d}$ & - & - & - & - \\
\hline D-Sorbitol & d & $-\S$ & $\mathrm{d}$ & - & Not known \\
\hline Trehalose & - & $\mathrm{d}$ & $\mathrm{d}$ & - & Not known \\
\hline ONPF ( $\alpha$-fucosidase) & $\mathrm{d}$ & - & - & - & Not known \\
\hline
\end{tabular}

* Deviating strains occur.

$\dagger P$. avium indole-negative.

$\ddagger$ Aesculin, amygdalin, arbutin, cellobiose, gentiobiose, salicin and NPG ( $\alpha$-glucosidase).

$\S$ Bisgaard taxon 9 late positive.

easy. All members of cluster $3 \mathrm{~A}$ are indole-negative, whereas the members of cluster $3 \mathrm{~B}$ with the exception of Pasteurella avium biovar 2 (isolated from calf pneumonia) are indole-positive. Furthermore, the two biovars of $P$. avium are found in clusters $3 \mathrm{~A}$ and $3 \mathrm{~B}$, respectively, even though DNA-DNA hybridizations have shown $88 \%$ DNA binding between the two biovars (Mutters et al., 1985). However, only a single strain from $P$. avium biovar 2 has been investigated by 16S rRNA sequencing and DNA-DNA hybridization. Considering the discrepancies observed, these results ought to be reinvestigated, including more strains from each biovar before taxonomic conclusions can be drawn.

Most of the species classified as Actinobacillus sensu stricto (Mutters et al., 1989) were located in cluster 4A according to Dewhirst et al. (1993). The exceptions were $A$. capsulatus and Bisgaard taxon 5 which were located in clusters $3 \mathrm{C}$ and $4 \mathrm{~B}$, respectively. However, these species can phenotypically be separated from the other species in Actinobacillus sensu stricto. Actinobacillus capsulatus is sorbitol-positive, while Bisgaard taxon 5 ferments meso-inositol and is urease-negative. The mean sequence difference within genus Actinobacillus sensu stricto (as defined by DNA-DNA hybridizations) is $5 \cdot 0 \%(\mathrm{SD}=2 \cdot 3)$, which is considerably lower than that found for Pasteurella sensu stricto $(7.0 \%$, SD $=2 \cdot 5)$. By excluding $A$. capsulatus and Bisgaard taxon 5 the mean sequence difference within genus Actinobacillus is only $3 \cdot 1 \%(\mathrm{SD}=0 \cdot 7)$.

16S rRNA has not been sequenced for all members of Haemophilus sensu stricto (as defined by DNA-DNA hybridizations). Consequently, calculation of sequence similarities has not been performed for this genus.

Based upon a combination of chemotaxonomic and physiological properties and genetic characterization, including determination of $\mathrm{G}+\mathrm{C}$ content of DNA and 16S rRNA analysis, a new genus and species of the family Pasteurellaceae Pohl 1981, Lonepinella koalarum, was proposed (Osawa et al., 1995) and subsequently validated (Osawa et al., 1996). Following the same lines and in agreement with current recommendations in defining genera (Murray et al., 1990) it is possible to identify and separate the $[P$. $]$ haemolytica complex from existing genera based upon 16S rRNA sequence analysis and the phenotypical characters shown in Table 8.

The $[P$.] haemolytica complex can be separated from genus Pasteurella by not producing acid from D- 
mannose and from a redefined genus Actinobacillus (excluding Bisgaard taxon 5) by being urease-negative and from genus Haemophilus (including $H$. influenzae, $H$. aegyptius, $[H$.] intermedius and $H$. haemolyticus) by being mannitol-positive. A negative Voges-Proskauer reaction separates the $[P$.] haemolytica complex from the new genus Lonepinella. Additional characters for separation of genera are listed in Table 8.

The trehalose-negative $[P$.] haemolytica complex has a common root relative to other strains within the family Pasteurellaceae according to the maximum-likelihood analysis, indicating that they have a common phylogenetic origin. In the bootstrap analysis, however, the five clusters were monophyletic in only $33 \%$ of the repeats. Representatives of the five $16 \mathrm{~S}$ rRNA clusters were also investigated by Davies et al. (1996) using the neighbour-joining method and a larger number of strains within Pasteurellaceae. The trehalose-negative $[P$.] haemolytica complex also formed a separate cluster in that analysis, increasing the confidence in the results obtained during the present investigation. In addition, the mean 16S rRNA sequence differences between representatives of the five clusters outlined for $[P$.] haemolytica in the present investigation was lower than that of the existing genera Actinobacillus sensu stricto and Pasteurella sensu stricto.

DNA binding levels of three of the five 16S rRNA clusters are lower than what was previously used to define genus boundaries within the family Pasteurellaceae (Mutters et al., 1989). Only strains representing clusters I and II show DNA binding values above $50 \%$. This might, however, be altered if additional isolates of $[P$.] haemolytica-like organisms are investigated. The correlation between DNA-DNA reassociation and 16S rRNA sequence analysis was discussed by Fox et al. (1992) and Stackebrandt \& Goebel (1994). According to these investigations, organisms that have less than $97 \%$ sequence homology will not reassociate to more than $60 \%$, no matter which hybridization method is used. Additionally, $16 \mathrm{~S}$ rRNA sequencing was not found to be sufficient for a reliable species delineation. Using the spectrophotometric method, $85 \%$ DNA binding has been found to correspond to well-defined species within the family Pasteurellaceae (Mutters et al., 1989). According to Fig. 4, no clear relationship could be observed between the DNA binding value used for species delineation and the corresponding $16 \mathrm{~S}$ rRNA sequence similarities within the $[P$.$] haemolytica complex. Strains having$ less than $97 \%$ sequence homology had DNA binding below $40 \%$ (Fig. 4). However, the standard deviations of the DNA hybridization experiments were quite high and made the separation of the two 'groups' less clearcut. Using single-linkage clustering on DNA binding values exaggerates these differences. This is reflected in Fig. 3 where strains belonging to $16 \mathrm{~S}$ rRNA clusters III-V and $[P$. $]$ trehalosi apparently were equally distantly related to $[P$.] haemolytica sensu stricto. However, a realistic image of the true distances and interrelationships based on DNA hybridization is only possible when a complete matrix of DNA binding values is available, which is unrealistic to obtain when a large number of strains is involved. Consequently, $16 \mathrm{~S}$ rRNA sequencing has been found to be more appropriate for determining phylogenetic relationships above species level (Murray et al., 1990). However, exact limits for genus delineation based upon $16 \mathrm{~S}$ rRNA sequence similarity has not yet been proposed as these probably differ depending on which group of organisms is being investigated (Murray et al., 1990).

In this investigation the present recommendations have been followed, relying on DNA binding values for species delineation (Wayne et al., 1987) and $16 \mathrm{~S}$ rRNA sequences for genus delineation (Murray et al., 1990). Furthermore, we regard the presence or the absence of phenotypic coherency among taxa as a deciding factor in the delineation of both species and genera (Wayne et al., 1987; Murray et al., 1990). As already mentioned, the trehalose-negative $[P$.] haemolytica complex can be phenotypically separated from the other genera of the family. Furthermore, the strains within the five 16S rRNA clusters were found phenotypically affiliated to such an extent that phenotypic delineation between some of the clusters is almost impossible, e.g. between clusters I and III and clusters IV and V. Separation of the five clusters into different genera therefore conflicts with current recommendations (Murray et al., 1990). A new genus, Mannheimia gen. nov., is therefore proposed for all taxa of the trehalose-negative $[P$.] haemolytica complex.

\section{S rRNA cluster I}

$[P$.$] haemolytica biogroup 1$ ([P.] haemolytica sensu stricto) was found as a separate and genetically homogeneous group by all methods used. Biogroup 1 included the type strain of $[P$.] haemolytica and reference strains of serotypes $1,2,5-9,12-14$ and 16 . The most divergent member of ribotype cluster 1 (strain 265) (Table 7) showed DNA binding of $91 \%$ with the type strain, indicating that all strains investigated from this biogroup belong to the same species. The only exception was strain UT26, which was found to deviate by all methods. It only showed DNA binding with the type strain of $52 \%$ and consequently represents a different species. However, none of the phenotypic tests used so far could separate this strain from the other strains of biogroup 1.

It should be noted that none of the biogroup 1 strains fermented L-arabinose (Table 9) even though they are referred to as 'biotype A'. For decades there has been contradictory reports as to whether or not $[P$.] haemolytica ferments L-arabinose. It is difficult to explain this simply as a result of differences in media and incubation conditions. We have found that if strains within the $[P$.] haemolytica complex ferment $\mathrm{L}-$ arabinose, $96.5 \%$ do so reproducibly within $2 \mathrm{~d}$, the remaining strains being positive within $7 \mathrm{~d}$. Negative strains are negative also after $14 \mathrm{~d}$ incubation (Angen 
Table 9. Phenotypic separation of species and taxa within genus Mannheimia, corresponding to the trehalose-negative [Pasteurella] haemolytica complex

Tests were performed according to the methods of Angen et al. (1997a). Table is based upon strains investigated by ribotyping and MEE by Angen et al. (1997c). Previous classifications: $M$. haemolytica was $[P$.] haemolytica biogroup $1 ; M$. glucosida was $[P$.] haemolytica biogroups 3 and $9 ; M$. granulomatis was $P$. granulomatis, $[P$. $]$ haemolytica biogroup $3 \mathrm{~J}$ and Bisgaard taxon 20 biovars 1 and $2 ; M$. ruminalis biovar 1 was Bisgaard taxon 18 biovars 1 and $3 ; M$. ruminalis biovar 2 was [P.] haemolytica biogroup 8D; M. varigena biovar 1 was Bisgaard taxon 15/biovar 1, Bisgaard taxon 36 and $[P$.] haemolytica biogroup 6; M. varigena biovar 2 was Bisgaard taxon 15/biovar 2. + , Strong or delayed positive (for fermentations: positive d $1-7) ;(+)$, weak or very weak positive (for fermentations : positive $8-14 \mathrm{~d}$ ) ; - , negative; d, + or - . Common characters for all biovars of the species $M$. glucosida, M. ruminalis and $M$. varigena are boxed. Origins: B, bovine; O, ovine; $\mathrm{P}$, porcine; L, leprine; $\mathrm{D}$, deer.

\begin{tabular}{|c|c|c|c|c|c|c|c|c|c|c|c|c|c|c|c|c|c|c|c|c|c|}
\hline \multirow[t]{2}{*}{ Species/taxon... } & \multirow[t]{2}{*}{ M. haemolytica } & \multicolumn{9}{|c|}{ M. glucosida } & \multicolumn{3}{|c|}{ M. granulomatis M. ruminalis } & \multicolumn{2}{|c|}{ M. varigena } & \multicolumn{6}{|c|}{ Unnamed taxa within Mannheimia } \\
\hline & & $\mathbf{A}$ & B & $\mathbf{C}$ & D & $\mathbf{E}$ & $\mathbf{F}$ & $\mathbf{G}$ & $\mathbf{H}$ & I & & 1 & 2 & 1 & 2 & $\mathbf{8 A}$ & 8B & $8 \mathrm{C}$ & 7 & $9^{*}$ & $10 \dagger$ \\
\hline Haemolysis & $(+)$ & $(+)$ & $(+)$ & $(+)$ & $(+)$ & $(+)$ & $(+)$ & $(+)$ & $(+)$ & $(+)$ & - & - & - & $\mathrm{d}$ & d & $(+)$ & $(+)$ & $(+)$ & $\mathrm{d}$ & $(+)$ & $\mathrm{d}$ \\
\hline Omithine decarboxylase & - & + & + & + & + & + & - & - & - & + & - & - & - & + & - & - & - & - & - & + & - \\
\hline L-Arabinose & - & + & - & + & + & - & - & + & - & + & - & $-\ddagger$ & - & + & + & - & - & - & + & + & + \\
\hline D-Sorbitol & + & + & + & + & + & + & + & + & + & + & + & $\mathrm{d}$ & - & - & - & - & - & - & - & + & + \\
\hline D-Xylose & $+/(+)$ & + & + & + & + & + & + & + & + & + & d & $\mathrm{d}$ & - & $+\S$ & + & + & + & - & $+\S$ & + & + \\
\hline Maltose & + & + & + & + & + & + & + & + & + & + & d & - & + & d & $\mathrm{d}$ & + & + & + & + & + & + \\
\hline Dextrin & + & + & + & + & + & + & + & + & + & + & d & - & $\mathrm{d}$ & $\mathrm{d}$ & $\mathrm{d}$ & + & $+/(+)$ & $+/(+)$ & $+/(+)$ & + & d \\
\hline Glucosides || & - & + & + & + & + & + & + & + & + & - & d & - & - & $\mathrm{d}$ & - & - & - & - & - & - & - \\
\hline Gentiobiose & - & + & + & - & + & + & $\div$ & + & + & - & d & - & - & - & $=$ & + & - & - & - & - & - \\
\hline NPG ( $\beta$-glucosidase) & - & + & + & + & + & + & + & + & + & + & + & - & - & $\mathrm{d}$ & $\mathrm{d}$ & - & - & - & - & - & - \\
\hline meso-Inositol & $\mathrm{d}$ & + & $+(+)$ & + & $+/(+)$ & $+/(+)$ & $+(+)$ & $+(+)$ & $+(+(+)$ & + & $\mathrm{d}$ & - & - & $\mathrm{d}$ & - & $(+y-$ & + & + & d & - & d \\
\hline ONPF ( $\alpha$-fucosidase) & + & $+/(+)$ & $+1(+)$ & + & + & $+/(+)$ & - & $+(+)$ & $+/(+)$ & + & - & - & - & $\mathrm{d}$ & - & + & - & - & - & - & $\mathrm{d}$ \\
\hline ONPX ( $\beta$-xylosidase) & d & + & + & - & - & - & + & - & - & d & $(+) /-$ & - & - & - & + & - & d & - & d & - & $\mathrm{d}$ \\
\hline ONPG ( $\beta$-galactosidase) & $\mathrm{d}$ & + & + & + & + & + & + & + & + & + & $\mathrm{d}$ & + & + & $\mathrm{d}$ & + & - & + & + & + & + & + \\
\hline Indole & - & - & - & - & - & - & - & - & - & - & - & - & - & d & - & - & $+h(+)$ & $+(+(+)$ & d & - & $(+) /$ \\
\hline D-Melibiose & - & - & - & - & $\ldots$ & - & - & - & - & - & - & - & - & $\mathrm{d}$ & - & - & - & - & - & - & - \\
\hline Origin of isolates & BO & 0 & $\mathrm{o}$ & $\mathrm{o}$ & 0 & $\mathrm{O}$ & 0 & 0 & o & 0 & BLD & $\mathrm{O}$ & BO & $\mathrm{BP}$ & $\mathrm{P}$ & $\mathrm{O}$ & B & B & BO & B & BO \\
\hline No. of strains & 30 & & & & 34 & & & & & & 28 & 12 & & 51 & & 5 & 2 & 3 & 7 & 3 & 8 \\
\hline
\end{tabular}

* meso-Inositol- and NPG-negative strains of [P.] haemolytica biogroup 9, the meso-inositol and NPG-positive strains reclassified as $M$. glucosida biovar I.

$\dagger$ Consisting of two genetically distinct groups that could not be phenotypically separated.

‡ Arabinose-positive strains of Bisgaard taxon 18 exist but their taxonomic allocation is still undecided.

$\S$ One strain negative.

|| Amygdalin, arbutin, aesculin (acid), cellobiose and salicin.

I Most strains negative for all glucosides; the strains that ferment glucosides also ferment D-melibiose.

et al., 1997a). Furthermore, we have shown that Larabinose is a reliable taxonomic marker correlating with genetic groups identified by ribotyping, MEE, 16S rRNA sequencing and DNA-DNA hybridization. L-Arabinose-positive strains, however, exist within the $[P$.] haemolytica complex, but they are genetically remote from $[P$.] haemolytica sensu stricto. Reports on isolation of $[P$.] haemolytica strains fermenting $\mathrm{L}-$ arabinose might therefore represent one of the Larabinose-positive taxa within the $[P$.] haemolytica complex (biogroups 3, 6, 7,9 and 10). On the other hand, all reference 'biotype $A$ ' serotypes (except serotype 11) have been found to belong to biogroup 1 , and it is at present an open and intriguing question whether these serotypes can be found within other taxa as well. Previous investigations have shown that some strains representing serotypes 11 and 14 might belong to biogroup 6 and some serotype 9 strains in biogroup 8 (Bisgaard \& Mutters, 1986). A pig isolate belonging to serotype 8 has also been reported (Biberstein \& Thompson, 1966). These observations question whether serotyping represents a reliable method for allocating strains to $[P$.] haemolytica sensu stricto. Mannheimia haemolytica comb. nov. is proposed as a new name for $[P$.] haemolytica biogroup 1.
Strains representing biogroups $3 \mathrm{~A}-3 \mathrm{H}$ and 9 clustered above $85 \%$ DNA binding, indicating that they should be regarded as biovars of the same species (Mutters et al., 1989), for which the name Mannheimia glucosida sp. nov. is proposed. They represent, however, a quite heterogeneous group. The different biovars (see Table 9) have been found to correspond to related, but distinct, MEE and ribotype clusters (Angen et al., $1997 \mathrm{c}$ ), and in Fig. 1 considerable diversity in $16 \mathrm{~S}$ rRNA sequences is reflected. The low values observed in the bootstrap analysis indicate that the branching pattern within cluster I is quite unstable and consequently should be interpreted with caution. Previous DNA-DNA hybridizations only included representatives of biogroups 3A, 3G, 3H and 9 (Mutters et al., 1986), and their low DNA binding values indicated that they represented different species. However, by including strains representing additional phenotypic and genetic variation we found that biogroups $3 \mathrm{~B}$ and $3 \mathrm{C}$ link the different sub-groups together as one DNA homology group. This underlines the importance of including strains representing as much as possible of the genetic variation and that analysis based upon a restricted data matrix might lead to biased conclusions. Mutters et al. (1986) reported that strain P733 
(biogroup $3 \mathrm{H}$ ) showed DNA binding of $85 \%$ with the type strain of $[P$.] haemolytica. As this was in conflict with the taxonomic structure previously outlined through analysis of MEE and ribotype data (Angen et al., $1997 \mathrm{c}$ ), this hybridization was repeated. These investigations showed DNA binding of $69 \%$ (mean of 10 experiments using two different DNA preparations), and we have confidence in this value due to the consistency obtained with the other methods applied.

Based upon 16S rRNA sequencing results, strains investigated by Davies et al. (1996) representing serotype 11 and untypable group 3 (UG3) probably belong to this DNA homology group as well. None of these strains had a sequence identical to strains that we investigated, but the UG3 strains are clearly affiliated to biogroups $3 \mathrm{H}$ and 9 according to Fig. 1. This is supported by the high values observed in the bootstrap analysis. All strains investigated within this putative DNA homology group have been isolated from sheep (except a bovine strain, UT23, from Davies' UG3), and the typable strains all belonged to serotype 11 . Serotype 11 was suggested as a third taxon of $[P$. haemolytica by Frederiksen (1973). More recent investigations have shown that serotype 11 differs from the other serotypes in a number of virulence factors (Murray et al., 1992; Burrows et al., 1993; Lee et al., 1994), supporting its separation as a new species. Davies et al. (1997) investigated the population structure of $[P$.] haemolytica using MEE. Here a clear separation between serotype 11 and UG3 (by Davies $e t$ al. called the 'A11 taxon') and the other 'A' serotypes of $[P$.$] haemolytica was demonstrated.$

Biogroup 8A of $[P$.] haemolytica also seems to represent a new species which is highly affiliated to the aforementioned groups. According to phenotypic tests, ribotyping and MEE, biogroup $8 \mathrm{~A}$ was the taxon showing the highest similarity to $[P$.] haemolytica sensu stricto (Angen et al., 1997a, c). However, by 16S rRNA sequencing it was found most affiliated to biogroup 3 . The strains of biogroup $8 \mathrm{~A}$ have all been isolated from the rumen or mouth of sheep. It differs from biogroups 1 and 3 by not fermenting D-sorbitol and from biogroup 3 by not fermenting glucosides. Due to the limited number of strains isolated so far, no formal species name is proposed for this taxon.

\section{$16 S$ rRNA cluster II}

Biogroup 8D of [P.] haemolytica, Bisgaard taxon 18, three strains of biogroup 10 of $[P$.] haemolytica and strain UT26 of biogroup 1 showed high affiliations both by ribotyping and by MEE. Representatives of biogroup 8D (HPA98) and Bisgaard taxon 18 (HPA92 and HPA109) showed DNA binding at or above $88 \%$, which qualifies their allocation to the same species, for which the name Mannheimia ruminalis sp. nov. is proposed. The two strains representing Bisgaard taxon 18 were located in different clusters by ribotyping (Table 7). In these ribotype clusters also represen- tatives of taxon 18 biovars 2 and 4 (both are arabinosepositive taxa) were loosely connected, indicating that all biovars of taxon 18 might belong to the same species. Additional DNA-DNA hybridizations including biovars 2 and 4 of taxon 18 should, however, be performed before firm conclusions can be drawn.

Strain UT26 which shares the phenotypical characters of biogroup 1 showed DNA binding of $83 \%$ with $M$. ruminalis and DNA binding of $84 \%$ with strain UT27 (biogroup 10 of $[P$.] haemolytica). The taxonomic allocation of these strains is still undecided. Strain UT27 was also investigated by Davies et al. (1996), who classified it in the untypable group 1 (UG1). Another UG1 strain was found by Davies et al. (1996) to have a $16 \mathrm{~S}$ rRNA sequence identical to $[P$.] haemolytica biogroup 1. Our findings indicate that UG1 is genetically heterogeneous as strain UT27 only had DNA binding of $42 \%$ with [P.] haemolytica sensu stricto.

\section{S rRNA cluster III}

Bisgaard taxon 20 biovars 1 and 2, $[P$.] haemolytica biogroup $3 \mathrm{~J}$ and $P$. granulomatis were linked above $85 \%$ DNA binding (Fig. 3) and should consequently be regarded as the same species, Mannheimia granulomatis comb. nov. Taxon 20 represents strains isolated from conjunctivitis and bronchopneumonia in hares and rabbits (Devriese et al., 1991), in addition to a single isolate from a deer. $P$. granulomatis represents strains isolated from skin granulomas in cattle in Brazil (Ribeiro et al., 1989; Riet-Correa et al., 1992). The taxonomic proximity between taxon 20 and $P$. granulomatis was supported by MEE (Table 7). In addition, ribotyping indicated that biogroup $3 \mathrm{~J}$ of $[P$. $]$ haemolytica (representing strains isolated from cattle and deer) was affiliated to both of these groups. This observation was confirmed by DNA-DNA hybridization.

\section{5 rRNA cluster IV}

16S rRNA cluster IV branched into two lines (Fig. 1). One branch included two strains representing Bisgaard taxon 15 while the other included biogroup 6 of $[P$.] haemolytica and Davies' untypable group 4 (UG4). UG4 and biogroup 6 obviously represent the same taxon as UG4 strain PH360 has a 16S rRNA sequence identical to strain 177 of biogroup 6, while the other UG4 strain (UT35) previously has been classified as biogroup 6 by Bisgaard \& Mutters (1986). Both taxa had been isolated from the respiratory tract and intestines, taxon 15 from pigs and biogroup 6 from ruminants, mostly cattle. Some of the isolates have been associated with pneumonia and septic conditions. Previous investigations have shown that some of the taxon 15 strains have a ribotype identical with certain biogroup 6 strains (Angen et al., 1997c). Furthermore, it is impossible to separate biogroup 6 of [P.] haemolytica and taxon 15 biovar 1 by the 79 phenotypic tests 
used so far (Angen et al., 1997a, b), the only difference between the two taxa being the species from which they were isolated. DNA-DNA hybridizations showed that biogroup 6 and Bisgaard taxon 15 biovar 1 had DNA binding of $85 \%$ which supports their inclusion in the same species for which the name Mannheimia varigena sp. nov. is proposed. Bisgaard taxon 36 had DNA binding of $88 \%$ to biogroup 6 thereby confirming the high genetic affiliation between these groups found by ribotyping (Angen et al., 1997c).

Taxon 15 biovar 2 has not been investigated by $16 \mathrm{~S}$ rRNA sequencing and DNA-DNA hybridization, but a previous investigation has shown that some strains from the two biovars of taxon 15 have identical ribotypes (Angen et al., 1997c), indicating that Bisgaard taxon 15 biovar 2 also should be included in $M$. varigena and that differences in ornithine decarboxylase have no taxonomic significance within this species. However, phenotypic separation between these strains and biogroup 7 of $[P$.] haemolytica has not been possible (Table 9), the only difference being the origin of isolation.

\section{5 rRNA cluster $V$}

Cluster V included representatives of biogroups 7 and 10 of $[P$.] haemolytica and Davies' UG5. Correspondingly, DNA binding values between 68 and $72 \%$ were found between biogroups $7,8 \mathrm{C}$ and 10 . The taxonomic relatedness between these taxa is further supported by observations based upon ribotyping and MEE (Table 7). Biogroup 10 was found to be heterogeneous by DNA-DNA hybridization as strains UT27 and HPA121 only had DNA binding of $9 \%$. The separation of biogroup 10 into two genetically distinct groups is in accordance with the results obtained by analysis of ribotypes and MEE (Angen $e t$ $a l ., 1997 \mathrm{c})$. However, none of the phenotypic tests used so far have been able to separate these two groups. Furthermore, ribotyping and MEE indicated that biogroups $8 \mathrm{~B}, 12$ and the $\beta$-glucosidase and mesoinositol-negative strains of biogroup 9 are affiliated to biogroups 7 and 10 . Further DNA-DNA hybridizations are necessary to draw conclusions about the taxonomic interrelationships between these groups, and new species are consequently not proposed for taxa within $16 \mathrm{~S}$ rRNA cluster $\mathrm{V}$ at the present stage.

\section{Description of Mannheimia gen. nov.}

Mannheimia (Mann.heim'i.a. L. fem. n. Mannheimia named in tribute to Walter Mannheim, a German microbiologist whose research has improved our understanding of the taxonomy of the family Pasteurellaceae).

Mannheimia is a new genus within the family Pasteurellaceae Pohl (1979) 1981. Consists of Gramnegative, non-motile rods or coccobacilli. Endospores are not formed. Growth is mesophilic and facultatively anaerobic or microaerophilic. Glucose is fermented without gas production. Oxidase reaction is normally positive but might be variable. Alkaline phosphatase test is positive and nitrate is reduced. Simmon's citrate test and arginine dihydrolase test are negative and there is no fermentation of adonitol or L-sorbose. All strains ferment mannitol. Urease reaction is negative, trehalose and D-mannose are not fermented. The phenotypic characters separating genus Mannheimia from the other genera of Pasteurellaceae are given in Table 8 . The type species is Mannheimia haemolytica (Pasteurella haemolytica Newsom and Cross 1932).

\section{Description of Mannheimia haemolytica comb. nov. (Pasteurella haemolytica Newsom and Cross 1932)}

Mannheimia haemolytica (haem.o.ly'ti.ca. Gr. n. haima blood; Gr. lyt- adjectival form of verb lyo loosen, dissolve; Gr. adjectival suff. -ikos Latinized as -icus, fem. -ica; M.L. adj. haemolytica referring to the haemolysis seen on blood agar).

Corresponds to $[P$.] haemolytica biogroup 1 (Bisgaard $\&$ Mutters, 1986). Cells are Gram-negative, non-motile small rods and coccobacilli. Colonies are smooth and greyish on blood agar and are 1-2 $\mathrm{mm}$ in diameter after $24 \mathrm{~h}$ incubation. Most strains show a characteristic $\beta$-haemolysis on bovine blood agar. Biochemical characteristics important for characterization are listed in Table 9 and under the description of the genus Mannheimia. D-sorbitol, D-xylose, maltose and dextrine are fermented. No strains ferment $\mathrm{L}$-arabinose or glucosides. Strains are negative for ornithine decarboxylase and NPG ( $\beta$-glucosidase) and positive for ONPF ( $\alpha$-fucosidase). Isolated from pneumonia in cattle and sheep and from septicaemia in lambs and mastitis in ewes. Some of the serotypes are probably part of the resident microflora of the upper respiratory tract of ruminants (Frank, 1989; Gilmour \& Gilmour, 1989). A total of 17 serotypes have been described within $[P$.] haemolytica, among which serotypes 3, 4, 10 and 15 now are classified as [Pasteurella] trehalosi. Representatives of serotypes 1, 2, 5, 6, 7, 8, 9, 12, 13, 14 and 16 are found in Mannheimia haemolytica. Serotype 11 is reclassified as Mannheimia glucosida. The type strain is NCTC $9380^{\mathrm{T}}\left(=\mathrm{J}\right.$. A. Watt $1266 \mathrm{~A} \& \mathrm{~B}^{\mathrm{T}}=$ CCUG $12392^{\mathrm{T}}$ ) isolated from sheep in the UK in 1956. The type strain represents serotype 2 , is ONPX- $(\beta$ xylosidase) and ONPG-negative and shows a late meso-inositol fermentation. The $\mathrm{G}+\mathrm{C}$ content of the DNA of the type strain is $43.6 \mathrm{~mol} \%$.

\section{Description of Mannheimia granulomatis comb. nov. (Pasteurella granulomatis Ribeiro et al. 1990)}

Mannheimia granulomatis (gran.nu.lo'ma.tis. L. dim. n. granulum a small grain; Gr. suff. -oma a swelling or tumour; M.L. n. granuloma a granuloma; M.L. n. granulomatis of a granuloma).

Cells are Gram-negative, non-motile small rods and coccobacilli. Colonies are smooth and greyish on 
blood agar and are 1-2 $\mathrm{mm}$ in diameter after $24 \mathrm{~h}$ incubation. No strains were haemolytic on bovine blood agar, but they have been reported as haemolytic using ovine blood (Ribeiro et al., 1989). All strains are negative for ornithine decarboxylase and ONPF and positive for NPG and fermentation of D-sorbitol. Strains are variable in fermentation of D-xylose, maltose, dextrin, glucosides and meso-inositol. Further biochemical characteristics are listed in Table 9 and under the description of the genus Mannheimia. The species includes the following taxa: Pasteurella granulomatis, isolated from bovine panniculitis (Ribeiro et al., 1989, 1990; Riet-Correa et al., 1992), Bisgaard taxon 20 biovars 1 and 2 isolated from bronchopneumonia and conjunctivitis in leprine species and deer (Devriese et al., 1991; Angen et al., $1997 \mathrm{~b}$ ), and $[P$.] haemolytica biogroup $3 \mathrm{~J}$ isolated from deer and the oral cavity of cattle (Angen et al., 1997a). The type strain is ATCC $49244^{\mathrm{T}}\left(=26^{\mathrm{T}}\right)$, isolated from bovine panniculitis in Brazil, previously classified as Pasteurella granulomatis (Ribeiro et al., 1989). The type strain is ONPG-positive and ferments maltose, dextrin, glucosides and meso-inositol, but not $\mathrm{D}$-xylose. The $\mathrm{G}+\mathrm{C}$ content of the type strain is $39 \cdot 2 \mathrm{~mol} \%$.

\section{Description of Mannheimia glucosida sp. nov.}

Mannheimia glucosida (glu.co'si.da. Gr. adj. glukus sweet; L. adj.-forming suff. -os rich in; L. adj.-forming suff. -id(us), fem. -ida; M.L. adj. glucosida pertaining to glucosides, which are fermented by almost all biovars).

Corresponds to Frederiksen's third taxon of $[P$.] haemolytica (Frederiksen, 1973), classified as $[P$.] haemolytica biogroups 3 and 5 by Bisgaard \& Mutters (1986) and reclassified as $[P$.] haemolytica biogroups 3A-3H by Angen et al. (1997a). The species also includes NPG and meso-inositol-positive strains of $[P$.] haemolytica biogroup 9 (Bisgaard \& Mutters, 1986). M. glucosida is correspondingly listed as biovars A-I in Table 9. Cells are Gram-negative, non-motile small rods. Colonies are smooth and greyish on blood agar and are $1-2 \mathrm{~mm}$ in diameter after $24 \mathrm{~h}$ incubation. All strains are haemolytic on bovine blood agar. All strains ferment D-sorbitol, D-xylose, maltose and dextrin. ONPG and NPG tests are positive for all biovars. The biovars are separated by differences in ornithine decarboxylase, ONPX, ONPF and fermentation of $\mathrm{L}$ arabinose and glucosides. Further biochemical characteristics are listed in Table 9 and under the description of the genus Mannheimia. Typable strains within $M$. glucosida all belong to serotype 11 (Angen et al., 1999). All strains investigated have been isolated from sheep, although isolates of serotype 11 have been reported from cattle (Quirie et al., 1986). This group of bacteria is normally not associated with disease conditions and probably represents part of the resident microflora in the upper respiratory tract (Biberstein \& Gills, 1962). The type strain is $\mathrm{P}^{2} 25^{\mathrm{T}}$ (numbering according to SSI
Strain Collection $=$ CCUG $38457^{\mathrm{T}}$ ), originally received as B558 from Moredun Research Institute. It was isolated from ovine lung in UK, and belongs to biovar B and serotype 11 (Angen et al., 1997a). The $\mathrm{G}+\mathrm{C}$ content of the type strain is $41.6 \mathrm{~mol} \%$.

\section{Description of Mannheimia ruminalis sp. nov.}

Mannheimia ruminalis (ru.mi.na'lis. L. n. rumen stomach, esp. first stomach of ruminants; L. adj.forming suff. -alis; M.L. adj. ruminalis referring to ruminants, from which the bacteria have been isolated).

Cells are Gram-negative, non-motile, non-haemolytic small rods or coccobacilli. Colonies are smooth and greyish on blood agar and are 1-2 $\mathrm{mm}$ in diameter after $24 \mathrm{~h}$ incubation. All strains are negative for ornithine decarboxylase, NPG, ONPF and ONPX and do not ferment L-arabinose, meso-inositol or glucosides (Table 9). For further biochemical characteristics, reference is made to the description of the genus Mannheimia. $M$. ruminalis consists of two distinct phenotypic groups. Biovar 1 consists of strains which do not ferment maltose and dextrin and show variable reactions in fermentation of $D$-sorbitol and $D-$ xylose and correspond to Bisgaard taxon 18 biovars 1 and 3 (Bisgaard et al., 1986; Angen et al., 1997b). Biovar 2 corresponds to $[P$.] haemolytica biogroup $8 \mathrm{D}$ (Angen et al., 1997a). All strains have been isolated from the rumen of sheep or cattle and were not associated with disease conditions. The strains have previously been decribed as $A$. lignieresii (Phillips, $1961,1964,1966)$. The type strain is HPA92 ${ }^{\mathrm{T}}$ (numbering according to RVAU Strain Collection = CCUG $38470^{\mathrm{T}}$ ), originally isolated as strain $\mathrm{S} 1 / 15 / 6$ from rumen of sheep in UK by J. E. Phillips, previously classified as Bisgaard taxon 18 biovar 1 (Bisgaard et al., 1986). The type strain belongs to biovar 1 and does not ferment D-sorbitol and D-xylose.

\section{Description of Mannheimia varigena sp. nov.}

Mannheimia varigena (va.ri'ge.na. L. adj. varia varied; L. adj.-forming element -gena orginating from; L. adj. varigena of different origin, referring to the isolation of strains of this species both from ruminants and from pigs).

Cells are Gram-negative, non-motile, small rods or coccobacilli. Colonies are smooth and greyish on blood agar and are $1-2 \mathrm{~mm}$ in diameter after $24 \mathrm{~h}$ incubation. Most strains are haemolytic on bovine blood agar. All strains ferment L-arabinose and Dxylose but not D-sorbitol. Most strains do not ferment glucosides, those fermenting glucosides also ferment D-melibiose. Most strains are ornithine decarboxylasepositive (biovar 1) and correspond to $[P$.] haemolytica biogroup 6, Bisgaard taxon 36 and Bisgaard taxon 15 biovar 1. Ornithine decarboxylase-negative strains (biovar 2) were isolated from pigs and correspond to 
Bisgaard taxon 15 biovar 2. Strains of $M$. varigena have been isolated from pneumonia, mastitis and septicaemia in cattle as well as from the oral cavity, rumen and intestines (Angen et al., 1997a). Isolates from pigs have been associated with septicaemia, enteritis or pneumonia and have also been isolated from the upper respiratory tract (Bisgaard, 1984; McLaughlin et al., 1991; Angen et al., 1997b). The type strain is $177^{\mathrm{T}}$ (= CCUG $38462^{\mathrm{T}}$ ), isolated from bovine pneumonia in Western Germany, previously classified as [P.] haemolytica biogroup 6 (Bisgaard \& Mutters, 1986). This strain is indole-negative, ONPG and ONPF-positive, NPG-negative, ferments maltose and meso-inositol, but not dextrin. The $\mathrm{G}+\mathrm{C}$ content of the DNA of the type strain in $41.7 \mathrm{~mol} \%$.

\section{ACKNOWLEDGEMENTS}

The study was supported by the Danish Agricultural and Veterinary Research Council (grant no. 9600803). The authors would like to thank Dr Sten Ebbesen, Institute for Greek and Latin, University of Copenhagen, for help with the Latin names.

\section{REFERENCES}

Angen, ø., Aalbæk, B., Falsen, E., Olsen, J. E. \& Bisgaard, M. (1997a). Phenotypical relationship among strains classified with the ruminant [Pasteurella] haemolytica-complex using quantitative evaluation of phenotypic data. Zentbl Bakteriol 285, 459-479.

Angen, Ø., Olsen, J. E. \& Bisgaard, M. (1997b). Further studies on the relationships among strains classified as tax on 15 , taxon 18 , taxon 20, [Pasteurella] granulomatis or the [Pasteurella] haemolytica-complex in ruminants using quantitative evaluation of phenotypic data. Zentbl Bakteriol 286, 317-332.

Angen, Ø., Caugant, D. A., Olsen, J. E. \& Bisgaard, M. (1997c). Genotypic relationships among strains classified within the [Pasteurella] haemolytica-complex as indicated by ribotyping and multilocus enzyme electrophoresis. Zentbl Bakteriol 286, 333-354.

Angen, Ø., Quirie, M., Donachie, W. \& Bisgaard, M. (1999). Investigations on the species specificity of Mannheimia (Pasteurella) haemolytica serotyping. Vet Microbiol (in press).

Biberstein, E. L. \& Francis, C. K. (1968). Nucleic acid homologies between the A and T types of Pasteurella haemolytica. $J \mathrm{Med}$ Microbiol 1, 105-108.

Biberstein, E. L. \& Gills, M. G. (1962). The relationship of the antigenic types of the $\mathrm{A}$ and $\mathrm{T}$ types of Pasteurella haemolytica. J Comp Pathol 72, 316-320.

Biberstein, E. L. \& Thompson, D. A. (1966). Epidemiological studies on Pasteurella haemolytica in sheep. J Comp Pathol 76, 83-94.

Biberstein, E. L., Gills, M. \& Knight, H. (1960). Serological types of Pasteurella haemolytica. Cornell Vet 50, 283-300.

Bingham, D. P., Moore, R. \& Richards, A. B. (1990). Comparison of DNA:DNA homology and enzymatic activity between Pasteurella haemolytica and related species. Am J Vet Res $\mathbf{5 1}$ 1161-1166.

Bisgaard, M. (1984). Comparative investigations of Pasteurella haemolytica sensu stricto and so-called $P$. haemolytica isolated from different pathological lesions in pigs. Acta Pathol Microbiol Immunol Scand Sect B 92, 201-207.
Bisgaard, M. (1995). Taxonomy of the family Pasteurellaceae Pohl 1981. In Haemophilus, Actinobacillus, and Pasteurella, pp. 1-7. Edited by W. Donachic, F. A. Lainson \& J. C. Hodgson. Proceedings from the Third International Conference on Haemophilus, Actinobacillus, and Pasteurella, July 31-August 4, 1993, Edinburgh, UK. London: Plenum.

Bisgaard, M. \& Mutters, R. (1986). Reinvestigations of selected bovine and ovine strains previously classified as Pasteurella haemolytica and description of some new taxa within the Pasteurella haemolytica-complex. Acta Pathol Microbiol Immunol Scand Sect B 94, 185-193.

Bisgaard, M., Phillips, J. E. \& Mannheim, W. (1986). Characterization and identification of bovine and ovine Pasteurellaceae isolated from the oral cavity and rumen of apparently normal cattle and sheep. Acta Pathol Microbiol Immunol Scand Sect B 94, 9-17.

Brosius, J., Palmer, M. L., Kennedy, P. J. \& Noller, H. F. (1978). Complete nucleotide sequence of a $16 \mathrm{~S}$ ribosomal RNA gene from Escherichia coli. Proc Natl Acad Sci USA 75, 4801-4905.

Burrows, L. L., Olah-Winfield, E. \& Lo, R. Y. C. (1993). Molecular analyses of the leucotoxin determinants from Pasteurella haemolytica serotypes 1 to 16. Infect Immun 61, 5001-5007.

Davies, R. L., Paster, B. J. \& Dewhirst, F. E. (1996). Phylogenetic relationships and diversity within the Pasteurella haemolytica complex based on 16S rRNA sequence comparison and outer membrane protein and lipopolysaccharide analysis. Int $J$ Syst Bacteriol 46, 736-744.

Davies, R. L., Arkinsaw, S. \& Selander, R. K. (1997). Evolutionary genetics of Pasteurella haemolytica isolates recovered from cattle and sheep. Infect Immun 65, 3585-3593.

De Ley, J., Cattoir, H. \& Reynaerts, A. (1970). The quantitative measurement of DNA hybridization from renaturation rates. Eur J Biochem 12, 133-142.

De Ley, J., Mannheim, W., Mutters, R. \& 7 other authors (1990). Inter- and intrafamilial similarities of the rRNA cistrons of the Pasteurellaceae. Int J Syst Bacteriol 40, 126-137.

Devriese, L. A., Bisgaard, M., Hommez, J., Uyttebroeck, E., Ducatelle, R. \& Haesebrouck, F. (1991). Taxon 20 (Fam. Pasteurellaceae) infections in European brown hares (Lepus europaeus). $J$ Wildl Dis 27, 685-687.

Dewhirst, F. E., Paster, B. J., Olsen, I. \& Fraser, G. J. (1992). Phylogeny of 54 representative strains of species in the family Pasteurellaceae as determined by comparison of 16S rRNA sequences. J Bacteriol 174, 2002-2013.

Dewhirst, F. E., Paster, B. J., Olsen, I. \& Fraser, G. J. (1993). Phylogeny of the Pasteurellaceae determined by comparison of $16 \mathrm{~S}$ ribosomal ribonucleic acid sequences. Zentbl Bakteriol 279 , 35-44.

Donachie, W., Fraser, J., Quirie, M. \& Gilmour, N. J. L. (1984). Studies on strains of Pasteurella haemolytica not typable by the indirect haemagglutination test. Res Vet Sci 37, 188-193.

Fodor, L., Varga, J., Hajtos, I., Donachie, W. \& Gilmour, N. J. (1987). New serotype of Pasteurella haemolytica isolated in Hungary. Vet Rec 121, 155.

Fox, G. E., Wisotzkey, J. D. \& Jurtshuk, P. J. (1992). How close is close: 16S rRNA sequence identity may not be sufficient to guarantee species identity. Int J Syst Bacteriol 42, 166-170.

Frank, G. H. (1989). Pasteurellosis of cattle. In Pasteurella and Pasteurellosis, pp. 197-222. Edited by C. Adlam \& J. M. Rutter. London: Academic Press.

Fraser, J., Laird, S. \& Gilmour, N. J. L. (1982). A new serovar (biovar T) of Pasteurella haemolytica. Res Vet Sci 32, 127-128. 
Frederiksen, W. (1973). Pasteurella taxonomy and nomenclature. Contrib Microbiol Immun 2, 170-176.

Gillis, M., De Ley, J. \& De Cleene, M. (1970). The determination of molecular weight of bacterial genome DNA from renaturation rates. Eur J Biochem 12, 143-153.

Gilmour, N. J. L. \& Gilmour, J. S. (1989). Pasteurellosis of sheep. In Pasteurella and Pasteurellosis, pp. 223-262. Edited by C. Adlam \& J. M. Rutter. London: Academic Press.

Jones, F. (1921). A study of Bacillus bovisepticus. J Exp Med 34, 561-577.

Jukes, T. H. \& Cantor, C. R. (1969). Evolution of protein molecules. In Mammalian Protein Metabolism, pp. 21-132. Edited by H. N. Munro. New York: Academic Press.

Kirby, K. S., Fox-Carter, E. \& Guest, M. (1967). Isolation of deoxyribonucleic acid and ribosomal ribonucleic acid from bacteria. Biochem $J$ 104, 258-262.

Lane, D. (1991). 16S/23S rRNA sequencing. In Nucleic Acid Techniques in Bacterial Systematics, pp. 115-147. Edited by E. Stackebrandt \& M. Goodfellow. New York: Wiley.

Lee, C. W., Shewen, P. E., Cladman, W. M., Conlon, J. A. R., Mellors, A. \& Lo, R. Y. C. (1994). Sialoglycoprotease of Pasteurella haemolytica A1 : detection of antisialoglycoprotease antibodies in sera of calves. Can J Vet Res 58, 93-98.

McLaughlin, B. G., Greer, S. C., Chengappa, M. M., Singh, S., Maddux, R. L., Kadel, W. L. \& McLaughlin, P. S. (1991). Association of a Pasteurella haemolytica-like organism with enteritis in swine. J Vet Diagn Invest 3, 324-327.

Mannheim, W. (1983). Taxonomy of the family Pasteurellaceae Pohl 1981 as revealed by DNA:DNA hybridization. INSERM 114, $211-226$.

Marmur, J. (1961). A procedure for the isolation of deoxyribonucleic acid from micro-organisms. $J$ Mol Biol 3, 208-218.

Marmur, J. \& Doty, P. (1962). Determination of the base composition of deoxyribonucleic acid from its thermal denaturation temperature. $J$ Mol Biol 5, 109-118.

Mraz, O. (1969). Vergleichende Studie der Arten Actinobacillus lignieresii und Pasteurella haemolytica II. Pasteurella haemolytica Newsom and Cross, 1932. Zentbl Bakteriol Parasitendk Infektkrankh Hyg I Abt 209, 336-349.

Murray, J. E., Davies, R. C., Lainson, F. A., Wilson, C. F. \& Donachie, W. (1992). Antigenic analysis of iron-regulated proteins in Pasteurella haemolytica $\mathrm{A}$ and $\mathrm{T}$ biotypes by immunoblotting reveals biotype-specific epitopes. $J$ Gen Microbiol 138, 283-288.

Murray, R. G. E., Brenner, D. J., De Vos, P., Colwell, R. R., Goodfellow, M., Grimont, P. A. D., Pfennig, N., Stackebrandt, E. \& Zavarzin, G. A. (1990). International Committee on Systematic Bacteriology. Report of the ad hoc committee on approaches to taxonomy within the Proteobacteria. Int $J$ Syst Bacteriol 40, 213-215.

Mutters, R., Bisgaard, M. \& Pohl, S. (1986). Taxonomic relationship of selected biogroups of Pasteurella haemolytica as revealed by DNA:DNA hybridizations. Acta Pathol Microbiol Immunol Scand Sect B 94, 195-202.

Mutters, R., Ihm, P., Pohl, S., Frederiksen, W. \& Mannheim, W. (1985). Reclassification of the genus Pasteurella Trevisan 1887 on the basis of deoxyribonucleic acid homology, with proposals for the new species Pasteurella dagmatis, Pasteurella canis, Pasteurella stomatis, Pasteurella anatis and Pasteurella langaa. Int J Syst Bacteriol 35, 309-322.

Mutters, R., Mannheim, W. \& Bisgaard, M. (1989). Taxonomy of the group. In Pasteurella and Pasteurelloses, pp. 3-34. Edited by C. Adlam \& J. M. Rutter. London: Academic Press.

Mutters, R., Piechulla, K., Hinz, K.-H. \& Mannheim, W. (1985). Pasteurella avium (Hinz and Kunjara 1977) comb. nov. and Pasteurella volantium sp. nov. Int J Syst Bacteriol 35, 5-9.

Newsom, I. E. \& Cross, F. (1932). Some bipolar organisms found in pneumonia in sheep. $J$ Am Vet Med Assoc 80, 711-719.

Olsen, G. J., Matsuda, H., Hagstrom, R. \& Overbeek, R. (1994). fastDNAml: a tool for construction of phylogenetic trees of DNA sequences using maximum likelihood. Comput Appl Biosci 10, 41-48.

Osawa, R., Rainey, F., Fujisawa, T., Lang, E., Busse, H. J., Walsh, T. P. \& Stackebrandt, E. (1995). Lonepinella koalarum gen. nov., sp. nov., a new tannin-protein complex degrading bacterium. Syst Appl Microbiol 18, 368-373.

Osawa, R., Rainey, F., Fujisawa, T., Lang, E., Busse, H. J., Walsh, T. P. \& Stackebrandt, E. (1996). Lonepinella koalarum gen. nov., sp. nov. In Validation of the Publication of New Names and New Combinations Previously Effectively Published Outside the IJSB, List no. 56. Int J Syst Bacteriol 46, 362-363.

Paster, B. J. \& Dewhirst, F. E. (1988). Phylogeny of campylobacters, wolinellas, Bacteroides gracilis, and Bacteroides ureolyticus by $16 \mathrm{~S}$ ribosomal ribonucleic acid sequencing. Int $J$ Syst Bacteriol 38, 56-62.

Pegram, R. G., Roeder, P. L. \& Scott, J. M. (1979). Two new serotypes of Pasteurella haemolytica from sheep in Ethiopia. Trop Anim Health Prod 11, 29-30.

Phillips, J. E. (1961). The commensal role of Actinobacillus lignieresii. J Pathol Bacteriol 82, 205-208.

Phillips, J. E. (1964). Commensal actinobacilli from the bovine tongue. J Pathol Bacteriol 87, 442-444.

Phillips, J. E. (1966). Actinobacillus lignieresii: a study of the organism and its association with its hosts. DVM \& S thesis, University of Edinburgh.

Pohl, S. (1979). Reklassifiezierung der Gattung Actinobacillus Brumpt 1910, Haemophilus Winslow et al. 1917 and Pasteurella Trevisan 1887 anhand phänotypischer und molekular Daten, inbesondere der DNS-Verwandtschaften bei DNA:DNAHybridisierung in vitro und Vorschlag einer neuen Familie, Pasteurellaceae. Thesis, Fachbereich Biologie der PhilippsUniversität Marburg/Lahn.

Quirie, M., Donachie, W. \& Gilmour, N. J. (1986). Serotypes of Pasteurella haemolytica from cattle. Vet Rec 119, 93-94.

Ribeiro, G. A., Carter, G. R., Frederiksen, W. \& Riet-Correa, F. (1989). Pasteurella haemolytica-like bacterium from a progressive granuloma of cattle in Brazil. J Clin Microbiol 27, 1401-1402.

Ribeiro, G. A., Carter, G. R., Frederiksen, W. \& Riet-Correa, F. (1990). Pasteurella granulomatis sp. nov. In Validation of the Publication of New Names and New Combinations Previously Effectively Published Outside the IJSB, List no. 32. Int J Syst Bacteriol 40, 105-106.

Riet-Correa, F., Méndez, M. C., Schild, A. L., Ribeiro, G. A. \& Almeida, S. M. (1992). Bovine focal progressive fibrogranulomatous panniculitis (Lechiguana) associated with Pasteurella granulomatis. Vet Pathol 29, 93-103.

Rohlf, F. J. (1993). NTSYS-pc. Numerical taxonomy and multivariate analysis system. Version 1.80. New York: Applied Biostatistics.

Sanger, F., Nicklen, S. \& Coulson, A. R. (1977). DNA sequencing 
with chain-terminating inhibitors. Proc Natl Acad Sci USA 74, 5463-5467.

Smith, G. R. (1959). Isolation of two types of Pasteurella haemolytica from sheep. Nature 183, 1132-1133.

Smith, G. R. (1961). The characteristics of two types of Pasteurella haemolytica associated with different pathological conditions in sheep. J Pathol Bacteriol 81, 431-440.

Sneath, P. H. A. \& Sokal, R. R. (1973). Numerical Taxonomy. San Francisco: Freeman.

Sneath, P. H. \& Stevens, M. (1990). Actinobacillus rossii sp. nov., Actinobacillus seminis sp. nov., nom. rev., Pasteurella bettii sp. nov., Pasteurella lymphangitidis sp. nov., Pasteurella mairi sp. nov., and Pasteurella trehalosi sp. nov. Int J Syst Bacteriol 40, 148-153.

Stackebrandt, E. \& Goebel, B. M. (1994). Taxonomic note: a place for DNA-DNA reassociation and 16S rRNA sequence analysis in the present species definition in bacteriology. Int $J$ Syst Bacteriol 44, 846-849.

Wayne, L. G., Brenner, D. J., Colwell, R. R. \& 9 other authors (1987). International Committee on Systematic Bacteriology. Report of the ad hoc committee on reconciliation of approaches to bacterial systematics. Int J Syst Bacteriol 37, 463-464.

Younan, M. \& Wallmann, J. (1989). A new serovar of Pasteurella haemolytica from sheep in Syria. Trop Anim Health Prod 21, 87. 